\title{
Regulating Interrogations and Excluding Confessions in the United States: Balancing Individual Rights and the Search for the Truth
}

\author{
Jenia Iontcheva Turner
}

\begin{abstract}
This chapter discusses U.S. constitutional law surrounding the admissibility of confessions and the contexts in which the law demands exclusion and those in which a cost-benefit analysis by the court results in its inclusion. Justifications and practical effects of exclusionary rules and the public debates surrounding their use are explained. In the U.S., rights that are expressly protected by the Constitution - such as the right to remain silent, the right to be free from an unreasonable search or seizure, and the right to counsel—are weighed more heavily than the state's need to fully explore the facts in a criminal case. The values of fairness, dignity, privacy, and liberty embodied in these rights frequently outweigh the need for reliable fact finding. In deciding how to enforce these constitutional rights, however, U.S. courts are well aware of competing interests throughout the criminal justice system.
\end{abstract}

\section{Introduction}

Like other criminal justice systems, the U.S. system must balance, on the one hand, enforcing the criminal law and, on the other, protecting individual rights in the process. Reliable fact-finding is a prerequisite to the effective enforcement of criminal law and to just outcomes. Protection of individual rights often promotes reliable fact-finding, as when a ban on involuntary confessions prevents the introduction of unreliable testimony at trial. On occasion, however, the commitment to accurate fact-finding may conflict with individual rights in a particular case. One of the clearest examples of such a conflict occurs when a court must decide whether to admit reliable and probative evidence obtained in violation of constitutional rights.

In the United States, rights that are expressly protected by the Constitutionsuch as the right to remain silent, the right to be free from unreasonable search or

\footnotetext{
J. I. Turner ( $\square)$

SMU Dedman School of Law, Dallas, USA

e-mail: Jenia@mail.smu.edu

(C) The Author(s) 2019

S. Gless and T. Richter (eds.), Do Exclusionary Rules Ensure a Fair Trial?

Ius Gentium: Comparative Perspectives on Law and Justice 74,

https://doi.org/10.1007/978-3-030-12520-2_4
} 
seizure, and the right to counsel - are given more weight in the balance than the state's need to explore fully the facts in a criminal case. The values of fairness, dignity, privacy, and liberty embodied in these rights frequently outweigh the concern for reliable factfinding. But in deciding how to enforce these constitutional rights, U.S. courts have recognized the relevance of competing interests in the criminal justice system, such as the interest in truthseeking. In deciding whether to exclude evidence, for example, courts have considered whether exclusion is expressly required by the Constitution and whether the benefits of exclusion, such as deterring police misconduct, outweigh its costs to truthseeking.

This report examines U.S. constitutional law on admissibility of confessions and discusses the contexts in which the law demands exclusion and contexts in which a cost-benefit analysis has led courts to reject exclusion. The report further explains the justifications and practical effects of exclusionary rules and the public debates surrounding their use.

\section{Fact-Finding Procedure: Stages, Rules, and Actors}

Before examining the law that regulates the search for truth and the protection of individual rights in criminal cases, it is useful to review the stages and rules of the factfinding process and the actors involved in it. A brief overview of the structure and institutions of criminal justice helps illustrate more clearly how legal rules apply in practice.

\subsection{Stages and Rules}

In the U.S. criminal justice system, the investigative and trial stages of the criminal process are not as strictly delineated as they are in some inquisitorial systems. The investigation frequently continues after formal charges are filed and, in some cases, even after the trial has begun. Yet the actors who investigate-the police or other government agents - do so independently and without supervision from prosecutors. ${ }^{1}$ As a practical matter, police officers may end a case by choosing not to investigate further or not to arrest a suspect. ${ }^{2}$ In serious cases, however, police officers typically are held accountable by political pressure to maintain a high clearance rate.

\footnotetext{
${ }^{1}$ At the state level, police are generally not supervised by prosecutors during their investigations. While in some specialized units and in some larger urban counties, police may run applications for a warrant by a prosecutor, this is the exception rather than the rule. By contrast, at the federal level, prosecutors routinely review warrant applications and other key investigative decisions with agents.

${ }^{2}$ See Saltzburg/Capra, 2014 at 958-59.
} 
When police officers do identify a suspect and bring forward evidence to support a complaint, prosecutors decide whether and what charges to file with the court. In some jurisdictions, in felony cases, prosecutors must obtain an indictment through a grand jury composed of ordinary citizens. ${ }^{3}$ The grand jury has an investigative as well as a screening function. It can subpoena witnesses and documents to aid the investigation, and it must decide whether the evidence provides probable cause to confirm an indictment. A little over half of U.S. states rely on a different mechanism - a preliminary hearing to evaluate whether probable cause supports the charges brought by the prosecutor. Unlike the grand jury, the preliminary hearing is adversarial in nature and allows both the prosecution and the defense to present evidence to a neutral magistrate. Defendants may and frequently do waive preliminary hearings, and the case then proceeds directly to the trial court. Regardless of whether the case proceeds via a preliminary hearing or via a grand jury indictment, the prosecutor retains broad discretion over charging decisions. ${ }^{4}$

The next step in the process is frequently a plea hearing before the trial court, as the overwhelming majority of U.S. state and federal cases are resolved through guilty pleas rather than trials. Guilty pleas typically result from negotiations between the defense and the prosecution. The negotiations may occur at any point before or during trial, although the vast majority of cases are resolved before trial. A major advantage of the guilty plea, from the perspective of the prosecution, is that it abbreviates the investigation and dispenses with a trial, saving precious resources. In some cases, plea bargaining also induces defendants to reveal valuable information about other cases, thus contributing to the search for truth.

Yet the abbreviated process also increases the risk of inaccurate or unfair judgments. Recognizing this risk, state and federal rules require that, before accepting a guilty plea, the court must examine the record and the defendant to determine that the guilty plea is voluntary, knowing, and factually based. ${ }^{5}$ In practice, however, the plea hearing is typically perfunctory and courts rarely challenge the version of the facts negotiated by the parties and presented summarily at the hearing.

If the case is not resolved by a guilty plea, the defendant has the right to a jury trial. ${ }^{6}$ Evidence rules that apply at trial generally attempt to increase the accuracy

\footnotetext{
${ }^{3}$ Saltzburg/Capra, 2014 at 987 (noting that "slightly less than half" the states require the use of a grand jury for felonies).

${ }^{4} \mathrm{~A}$ judge or a grand jury may reject charges filed by a prosecutor, but the prosecutor retains the ultimate discretion to decline charges, even where a grand jury chooses to indict. Furthermore, as long as the evidence supports a charge, neither the grand jury nor the judge can question the prosecutor's choice about which of several possible charges the prosecutor chooses to file. Overlapping statutes frequently give prosecutors several choices of charges to pick from, often with different sentencing consequences.

${ }^{5}$ See, e.g., Federal Rules of Criminal Procedure (Rule 11 of 1 December 2016 as amended).

${ }^{6}$ Some defendants waive this right and opt for a bench trial. Note that, in some jurisdictions, the prosecution has to consent to the waiver of a jury trial. See Singer v. United States, 380 US 24, 36 (1965).
} 
and fairness of the process by preventing the jury from seeing certain overly prejudicial or potentially unreliable evidence. ${ }^{7}$ The trial is public, and a verbatim transcript is produced. The transcript can be used as needed for purposes of challenging and reviewing the verdict on appeal. Some jurisdictions also allow for the broadcasting of criminal proceedings, as discussed below in Sect. 3.4.2.

Unlike in inquisitorial systems, sentencing is a separate stage of the criminal process in the United States. It follows different, typically more relaxed rules of evidence and procedure from those at trial. For example, the Fourth Amendment exclusionary rule has been held not to apply at sentencing. ${ }^{8}$ The Privilege against Self-Incrimination, however, continues to apply at sentencing as it does at trial, and so does the rule requiring exclusion of coerced confessions. ${ }^{9}$

\subsection{Actors and Accountability}

At the state level, American police officers conduct investigations. Prosecutors are typically not involved in the investigations and do not have supervisory power over police officers, although they rely on the evidence collected by officers to support the charges they choose to file. ${ }^{10}$ At the federal level, prosecutors are more likely to take part in the investigation, particularly in more complex cases, such as those concerning white-collar crimes. ${ }^{11}$ Even at the federal level, however, prosecutors have no authority to discipline investigative agents, so their "supervision" is generally informal and limited to correcting errors as the investigation unfolds. ${ }^{12}$

Because prosecutors depend on police officers to obtain convictions in their cases, however, they often refrain from looking too closely for gaps and flaws in police investigations. ${ }^{13}$ More importantly, prosecutors typically lack the time and resources to adequately review police investigations in a thorough fashion. ${ }^{14}$ Finally, chief prosecutors at the state level are typically chosen in popular elections, and support by police unions is important for electoral success. Political calculations therefore further discourage critical oversight of police actions by prosecutors.

\footnotetext{
${ }^{7}$ See, e.g., Federal Rules of Evidence (Rules 403, 801, 802 of 1 December 2015 as amended).

${ }^{8}$ See United States v. Tejada, 956 F2d 1256, 1262-63 (2nd Cir. 1992).

${ }^{9}$ See Mitchell v. United States, 526 US 314, 325-27 (1999).

${ }^{10}$ Luna/Wade, 2010 at 1467-68; see also Geller, 1975 at 721 ("Historically, the American police department has been independent of the prosecutor's office: that is, neither police nor prosecutor directly gives or takes orders from the other. As a result, the prosecutor ... is unable to command police officers to conduct their searches within constitutional bounds.").

${ }^{11}$ See generally Richman, 1999 at 780; Richman, 2003 at 756-794.

${ }^{12}$ Richman, 2003 at $756-794$.

${ }^{13}$ See, e.g., Luna/Wade, 2010 at 1467-68; Laurin, 2014 at 817 (noting some recent departures from the traditional practice under which prosecutors do not oversee police investigations).

${ }^{14}$ See, e.g., Gershowitz/ Killinger, 2011 at 261.
} 
Courts provide a level of oversight over police conduct. With respect to searches and seizures, magistrate judges review warrant applications to ensure that these are based on probable cause. Magistrates reject warrant applications extremely rarely, however, causing some to argue that they are mere "rubber stamps for law enforcement." 15 On the other hand, the requirement to submit a warrant application may serve a valuable function on its own, causing police departments to invest in training their officers in constitutional criminal procedure and encouraging officers to consider the facts and the law more carefully before applying for a warrant.

In most arrests and searches, officers are not required to obtain a warrant. But even where no warrant is required before an arrest, magistrates must review the decision to detain a suspect within 48 hours of the arrest. Likewise, even where no warrant is required for a search, the defendant may challenge the legality of the search through a pretrial motion to suppress evidence obtained as a result of an unlawful search or seizure. Defendants may also move the court to exclude a confession that is involuntary or unreliable, or was obtained in violation of Miranda or the pretrial right to counsel. The exclusion of evidence continues to be regarded by most commentators as the most effective mechanism for holding police accountable for their investigative actions. As Sect. 3.3 discusses, however, the Supreme Court has become more skeptical of the usefulness of the exclusionary rule and has gradually restricted its scope. ${ }^{16}$ Indeed, the Court has limited the application of the rule in part because of a concern that in many cases, it interferes with the search for truth.

Beyond examining the legality of searches, arrests, and interrogations, judges could theoretically probe more deeply into the accuracy and completeness of investigations when they review charges at a preliminary hearing or on a defendant's motion to dismiss the indictment. Judges could also scrutinize the quality of the investigation when they examine whether a guilty plea is based on sufficient facts. In practice, however, judges have little information at their disposal about how an investigation has been conducted because they do not have access to an "investigative file." As a consequence, their ability to review the investigation for accuracy and completeness is limited in practice. Separation of powers principles further discourage judges from inquiring into investigative or charging decisions. ${ }^{17}$

When it comes to police misconduct during an investigation, a few other methods of accountability are potentially available. If police officers violate a person's constitutional rights, the person may bring a civil action requesting

\footnotetext{
${ }^{15}$ Saltzburg/Capra, 2014 at 108 (quoting Labaton, 'Before the Explosion, Official Saw Little Risk for Building in Oklahoma City', New York Times, 2 May 1995, A19).

${ }^{16}$ See below Sect. 3.3 .

${ }^{17}$ United States v. Janis, 428 US 433, 458-59 (1976) (noting that separation of powers principles limit judicial supervision of police misconduct); Rizzo v. Goode, 423 US 362 (1976) (same); Payner v. United States, 447 US 774, 737-38 (1980) (Chief Justice Burger, concurring); see also Bordenkircher v. Hayes, 434 US 357, 364-65 (1978) (noting the breadth of prosecutorial charging discretion).
} 
monetary compensation for damages. Civil actions have not proven very effective in disciplining police, however, for several reasons. First, officers are entitled to qualified immunity for their actions done in the course of performing official duties, so they can be held liable only if their conduct violates clearly established constitutional rules, a standard that is difficult to meet. ${ }^{18}$ Second, damages for an unlawful search are generally nominal, which discourages citizens from pursuing a lawsuit. Third, even where damages may be more substantial, plaintiffs have difficulty collecting the judgment, because individual officers are typically unable to pay, and governmental entities employing the officers are only liable where the injury resulted from the entity's custom or policy. ${ }^{19}$ Finally, civil actions typically concern violations of privacy or the use of excessive force, so they do little to improve reliable factfinding by police.

Officers may also be subject to discipline by external oversight mechanisms (citizen review boards) or internal ones (internal affairs investigators). Over a hundred departments around the country are at least partially supervised by review boards or commissions staffed by ordinary citizens, and these have increased the transparency and legitimacy of police work. ${ }^{20}$ Yet statistics from citizen review boards suggests that they are "more reluctant to second-guess officers than are officers themselves." 21 Moreover, they focus on resolving citizen complaints about police misconduct, which typically relate to excessive force, discourtesy, or invasions of privacy, rather than on unreliable factfinding.

Compared to citizen review boards, internal affairs divisions are more willing to impose discipline for officer misconduct. ${ }^{22}$ Unfortunately, scholars have not yet examined what makes internal affairs divisions effective, or the extent to which they have improved police accountability since the $1960 \mathrm{~s}^{23}$ Nor is it clear whether internal discipline, without an exclusionary rule as a backstop, could be effective on its own to deter misconduct. A study from California, where state constitutional law prohibits warrantless searches of trash placed on the curbside, but where exclusion for violations of this rule was abandoned in 1982, suggests that without exclusion, compliance with the underlying law suffers significantly. ${ }^{24}$ More empirical research is needed to examine whether internal discipline can operate effectively in the absence of judicial remedies such as exclusion.

Furthermore, internal disciplinary mechanisms have focused on limiting the use of force, improving police-citizen interactions, and preventing unwarranted

\footnotetext{
${ }^{18}$ See, e.g., Sklansky, 2008 at 572.

${ }^{19}$ Saltzburg/Capra, 2014 at 558 (citing Monell v. Department of Social Services, 436 US 658 (1978)).

${ }^{20}$ Finn, 2001 at 7-12; Sklansky, 2008 at 573.

${ }^{21}$ Sklansky, 2008 at 573.

${ }^{22}$ Ibid.

${ }^{23}$ Ibid.; see also Schwartz, 2012 at 870 ("[N]o outside reviewer has 'found the operations of internal affairs divisions in any of the major US cities satisfactory."').

${ }^{24}$ Sklansky, 2008 at $580-81$.
} 
invasions of privacy. ${ }^{25}$ They have not directly addressed the problems of incomplete or inaccurate investigations. An important obstacle to accuracy in investigations is the increased emphasis on efficiency as a goal of police departments. An emphasis on arrests and clearance rates encourages officers to clear cases quickly and discourages them from investigating more thoroughly and from following up on potentially exculpatory evidence. ${ }^{26}$ Of particular relevance to this report, officers have a strong incentive to obtain confessions so as to save the significant resources needed to investigate the case independently. ${ }^{27}$ Examination of wrongful conviction cases shows that once officers have obtained a confession, they rarely investigate further. ${ }^{28}$ This increases the risk that a wrongful confession remains uncorrected.

\section{General Framework for Fact-Finding in Criminal Proceedings}

\subsection{Law Relating to the Search for Truth}

In the United States, neither the Constitution nor criminal procedure codes expressly require investigators, prosecutors, or courts to seek truth. ${ }^{29}$ Yet U.S. courts and policymakers have recognized that accurate factfinding helps ensure the legitimacy of the verdict and the effective enforcement of criminal law. Numerous court decisions mention the search for truth as a guiding principle in criminal cases. $^{30}$

In pursuit of this goal, jurisdictions have adopted a range of evidence rules that aim to sort reliable from unreliable evidence. Accurate factfinding is often stated as an overarching goal of evidence rules. For example, the Federal Rules of Evidence are supposed to "be construed so as to administer every proceeding fairly, eliminate

\footnotetext{
${ }^{25}$ See, e.g., Schwartz, 2012 at 870.

${ }^{26}$ Fisher, 1993 at $20-21$.

${ }^{27}$ Fisher/Rosen-Zvi, 2008 at 878-79.

${ }^{28} \mathrm{Ibid}$. at 879; see also Garrett, 2012 at 35.

${ }^{29}$ For example, the Federal Criminal Procedure Rules suggest that the following principles should guide interpretation: "These rules are to be interpreted to provide for the just determination of every criminal proceeding, to secure simplicity in procedure and fairness in administration, and to eliminate unjustifiable expense and delay." Federal Rules of Criminal Procedure (Rule 2 of 1 December 2016 as amended).

${ }^{30}$ For example, in Tehan v. United States, the US Supreme Court stated that " $[\mathrm{t}] \mathrm{he}$ basic purpose of a trial is the determination of the truth." 383 US 406, 416 (1966); see also United States v. Havens, 446 US 620, 626 (1980) ("arriving at the truth is a fundamental goal of our legal system"); Colorado v. Connelly, 479 US 157, 166 (1986) ("[T]he central purpose of a criminal trial is to decide the factual question of the defendant's guilt or innocence," Delaware v. Van Arsdall, 475 US 673, 681 (1986), "and while we have previously held that exclusion of evidence may be necessary to protect constitutional guarantees, both the necessity for the collateral inquiry and the exclusion of evidence deflect a criminal trial from its basic purpose.”).
} 
unjustifiable expense and delay, and promote the development of evidence law, to the end of ascertaining the truth and securing a just determination." ${ }^{31}$ U.S. jurisdictions have also adopted special evidentiary safeguards to ensure the reliability of confessions admitted at trial. Some states require prosecutors to offer evidence corroborating the confessions before they can obtain a conviction ${ }^{32}$; other states and the federal system require judges to examine the trustworthiness of the confession and admit the confession only if it is found to be reliable by preponderance of the evidence. ${ }^{33}$

The commitment to an accurate determination of the facts is not absolute, however, and at times bends to other goals of the criminal justice system. The pursuit of efficiency, for example, has resulted in speedier resolutions of cases and less thorough and careful examination of the underlying facts. Over $95 \%$ of convictions in the United States today result from guilty pleas, which substitute consensual disposition of the case for an objective and thorough inquiry into the facts. Although judges must evaluate whether guilty pleas are voluntary, informed, and factually based, the "factual basis" requirement is very permissive. Under the pressure of heavy caseloads, judges typically conduct merely a cursory review of the facts, requiring little more than the defendant's confirmation that the allegations in the indictment are correct. ${ }^{34}$ In practice, courts and prosecutors frequently compromise the commitment to comprehensive fact-finding in order to obtain the efficiency benefits of guilty pleas.

Of greater relevance to this report, factfinding may also be constrained to some degree by protections of individual rights. The Privilege against Self-Incrimination, the ban on double jeopardy, rules for excluding unlawfully obtained evidence, and unreviewable jury acquittals may impair the search for truth. This interference with truthseeking is justified by reference to fundamental values, such as liberty, privacy, dignity, and fairness, which are expressly or implicitly incorporated in constitutional provisions.

In addition, the constraint on factfinding imposed by some of these constitutional provisions - notably, the Privilege against Self-Incrimination - may be justified by an underlying commitment to minimize particular types of erroneous outcomesnamely, wrongful convictions. In other words, following the Blackstone maxim that "it is better that ten guilty persons escape, than that one innocent suffer," the Privilege against Self-Incrimination may be read to be specially concerned with avoiding one type of inaccuracy — wrongful convictions - even at the expense of an overall increase in erroneous outcomes. ${ }^{35}$

\footnotetext{
${ }^{31}$ Federal Rules of Evidence (Rule 102 of 1 December 2015 as amended).

${ }^{32}$ See, e.g., Arkansas Code $\S 16-89-111(\mathrm{~d})$; Fisher/Rosen-Zvi, 2008 at 885.

${ }^{33}$ See, e.g., Fisher/Rosen-Zvi, 2008 at 886; see also Opper v. United States, 348 US 84, 90-93 (1954) (requiring substantial corroboration of confession).

${ }^{34}$ Brown, 2005 at 1611; Turner, 2006 at 212-23.

${ }^{35}$ For a more thorough discussion of this concern with error allocation, see, for example, Stacy, 1991, at 1406-09.
} 
Section 3.2 discusses these constitutional provisions in greater detail, and Sect. 3.3 examines how courts have balanced the need to protect individual rights against the interest in uncovering the truth and ensuring the effective enforcement of the criminal law.

\subsection{Law Protecting Individual Rights}

The Fourth, Fifth, and Sixth Amendments of the U.S. Constitution contain key provisions safeguarding individual rights in the criminal process. This part of the report focuses on aspects of the amendments that could give rise to exclusion of evidence and therefore may potentially conflict with the search for truth.

The Fourth Amendment protects "the people" from unreasonable searches and seizures. The Amendment also regulates the conditions on which warrants must be issued - they must be approved by a neutral magistrate, be based on probable cause, and particularly describe the place to be searched and the evidence to be seized. The Court has held that searches of houses and non-public arrests of individuals are presumed to be unreasonable unless they are conducted pursuant to a warrant. ${ }^{36}$ When it comes to searches of persons, cars, and other effects, courts have carved out exceptions to the warrant requirement, although the reasonableness requirement still applies. $^{37}$

Two other important provisions protecting individual rights in the criminal process are the Fifth Amendment's Privilege against Self-Incrimination and the Fourteenth Amendment's Due Process Clause. The former provides that no person should be compelled to be a witness against himself in a criminal case. The latter guarantees that no one shall be deprived of life, liberty, or property without due process of law. Due process is held to require a fair opportunity for a suspect to test the prosecution's case and to prohibit "inquisitorial" methods of investigation. ${ }^{38}$ Courts have relied on these provisions to regulate the methods by which police can obtain confessions and to exclude confessions obtained through torture or coercion. $^{39}$

\footnotetext{
${ }^{36}$ See, e.g., Kyllo v. United States, 533 US 27, 40 (2001); Payton v. New York, 445 US 573, 58688 (1980).

${ }^{37}$ See, e.g., California v. Carney, 471 US 386, 392-93 (1985) (warrantless search of car); United States v. Robinson, 414 US 218, 224 (1973) (warrantless search of person incident to arrest); Terry v. Ohio, 392 US 1, 20 (1968) (warrantless stop \& frisk); Arizona v. Gant, 556 US 332, 343 (2009) (warrantless search of car incident to arrest); United States v. Watson, 423 US 411, 423 (1976) (warrantless arrest of person in public); Schneckloth v. Bustamonte, 412 US 218, 219 (1973) (warrantless consent search).

${ }^{38}$ Gallegos v. Colorado, 370 US 49, 50-51 (1962); Chambers v. Florida, 309 US 227, 237 (1940); Watts v. Indiana, 338 US 49, 54-55 (1949).

${ }^{39}$ See below Part 4.1.
} 
Both the Due Process Clause and the Privilege against Self-Incrimination prohibit methods of interrogation that overwhelm the will of the accused. To determine what methods violate these provisions, courts use a totality of circumstances approach, which focuses above all on the coerciveness of police tactics, but also takes into account the characteristics of the accused and features of the environment in which the interrogation took place. More recent cases have clarified that personal characteristics of the suspect do not on their own render a confession invalid, absent some proof of police coercion. ${ }^{40}$

While an important concern about coerced confessions-from the common law rule preventing involuntary confessions until today-has been that they may be unreliable, police coercion appears to be the preeminent reason for suppressing involuntary confessions under contemporary constitutional doctrine. The Supreme Court has clarified that coercion may lead to exclusion even in situations where no question about the reliability of the confession exists: "The abhorrence of society to the use of involuntary confessions does not turn alone on their inherent untrustworthiness. It also turns on the deep-rooted feeling that the police must obey the law while enforcing the law." 41 Conversely, in the absence of police coercion, lack of reliability would be addressed under state or federal rules of evidence (potentially also leading to exclusion), rather than under the Constitution. ${ }^{42}$

The Fifth Amendment's Privilege against Self-Incrimination also prohibits lesser compulsion of a person, but only in the context of official proceedings. The privilege protects individuals from answering questions in any official process, including civil, legislative, or administrative proceedings, if the answers might harm the persons in future criminal proceedings. ${ }^{43}$ The level of compulsion needed to trigger this protection under the privilege is lower than that which renders a confession coerced in the context of police interrogations. While the threat of imprisonment or being held in contempt of court is the classic type of compulsion prohibited under the privilege, lesser compulsion may also suffice. For example, the threat of imposing economic sanctions for invoking the privilege is often enough. Economic sanctions may include the denial of government contracts ${ }^{44}$; disbarment $^{45}$; or dismissal from employment. ${ }^{46}$ Somewhat more controversially, the Supreme Court has also held that a comment, by the prosecutor or the court, on the defendant's invocation of the privilege also constitutes official compulsion that violates the privilege.

\footnotetext{
${ }^{40}$ Colorado v. Connelly, 479 US 157, 163 (1986). Thus, where a defendant confesses because he suffers from command hallucinations telling him to confess, or where a private party coerces the defendant to give a statement, this does not render the statement involuntary under the Due Process Clause.

${ }^{41}$ Spano v. New York, 360 US 315, 320 (1959).

${ }^{42}$ Colorado v. Connelly, 479 US 157, 159 (1986).

${ }^{43}$ See, e.g., Lefkowitz v. Turley, 414 US 70, 77 (1973).

${ }^{44}$ Lefkowitz v. Turley, 414 US 70, 82-83 (1973).

${ }^{45}$ Spevack v. Klein, 385 US 511, 516 (1967).

${ }^{46}$ Garrity v. New Jersey, 385 US 493, 500 (1967).
} 
In its famous ruling in Miranda v. Arizona, the U.S. Supreme Court extended the reach of the privilege further and held that the coercive environment of pretrial custodial interrogations constitutes the type of compulsion that has the potential to overwhelm the will of the accused. To dispel this coercive effect, before interrogation, officers must warn detained suspects of their right not to make a statement, of the risk that any statement can be used as evidence against them, of the right to consult a lawyer, and of the right to have an attorney appointed for them, if they cannot afford to retain one. After receiving the warnings, suspects may choose to waive their rights to remain silent and to have a lawyer present during the interrogation. The waiver must, however, be intelligent, knowing, and voluntary.

After a suspect has been formally charged, the Sixth Amendment right to an attorney attaches and governs interactions between the accused and government agents. Police may not deliberately elicit statements from an indicted defendant without providing the requisite warnings of the right to remain silent and to consult an attorney and then obtaining a valid waiver. ${ }^{47}$ The Sixth Amendment applies to undercover investigations as well, prohibiting the surreptitious elicitation of statements from an accused.

To enforce these rules contained in the Fourth, Fifth, and Sixth Amendments, courts frequently rely on evidentiary exclusion. Exclusion is justified on somewhat different grounds and has a different scope depending on which underlying rule is violated. It is automatic for statements taken in violation of the Due Process Clause or the Privilege against Self-Incrimination. When a statement is coerced under these provisions, it cannot be introduced at trial for any purpose, and even fruits of the statement are generally suppressed. Exclusion is not automatic, however, for violations of the Fourth Amendment, of the rules announced in Miranda v. Arizona, and of the ban on deliberate elicitation under the Sixth Amendment. The constitutional text does not expressly mandate exclusion as a remedy in these cases, and the Court has held that there are typically no reliability concerns for the evidence at issue.

Evidentiary exclusion was originally adopted because it was seen as necessary to effectuate constitutional guarantees inscribed in the Fourth, Fifth, and Sixth Amendments. Without exclusion, the Court held in an early Fourth Amendment case, provisions that protect fundamental rights would be reduced to "a form of words" 48 such that they "might as well be stricken from the Constitution."49

Most of the time, however, the Court has justified exclusion on the grounds that it helps discourage misconduct by police officers. Under this view, the "[exclusionary] rule is calculated to prevent, not to repair. Its purpose is to deter-to compel respect for the constitutional guaranty in the only effectively available

\footnotetext{
${ }^{47}$ Massiah v. United States, 377 US 201, 205 (1964); Montejo v. Louisiana, 556 US 778, 786-87 (2009).

${ }^{48}$ Silverthome Lumber Co. v. United States, 251 US 385, 392 (1920).

${ }^{49}$ Weeks v. United States, 232 US 383, 393 (1914). In the early days of the exclusionary rule, the Court also put forward judicial integrity as a reason for exclusion. Under this view, excluding unlawfully obtained evidence is necessary to protect the court from the taint of official illegality.
} 
way-by removing the incentive to disregard it."50 More recently, the Court has extrapolated from this focus on deterrence that the exclusionary rule should be used only when it would effectively dissuade law enforcement officials from violating the law in the future. ${ }^{51}$ If the deterrence potential of the rule is too negligible or if it is vastly outweighed by the costs of the exclusionary rule, then exclusion should not be imposed. $^{52}$

\subsection{Law Balancing the Search for Truth and Individual Rights Protections}

While U.S. courts mandate exclusion with respect to conduct that violates the Due Process Clause or the Privilege against Self-Incrimination, this is not always the case with respect to other constitutional violations in the investigative process. U.S. courts balance the costs and benefits of excluding evidence in certain cases involving Fourth Amendment violations, violations of Miranda v. Arizona, and violations of the Sixth Amendment pretrial right to counsel. The balancing process is not done on a case-by-case basis, but is rather done on a category-by-category basis. In other words, if the costs of exclusion for certain categories of evidence of for certain uses of the evidence outweigh the benefits, then exclusion is never imposed for that type or that use of evidence.

In the Fourth Amendment context, the conflict between truth-seeking and individual rights is expressly acknowledged in exclusionary rule decisions. In deciding whether to mandate exclusion for certain categories of evidence, the Supreme Court balances the benefits of exclusion-deterrence of police misconduct and protection of individual rights, against the costs of exclusion-interference with truthfinding and with the enforcement of criminal law. ${ }^{53}$ For example, the Court has held that at certain preliminary or non-criminal proceedings, such as grand jury, sentencing, deportation, or habeas, the likelihood of deterring police misconduct is too negligible to warrant exclusion of reliable evidence obtained in violation of the Fourth Amendment. ${ }^{54}$ As the Court has explained in the context of grand jury proceedings, "[a]ny incremental deterrent effect which might be achieved by extending the [exclusionary] rule to grand jury proceedings is uncertain at best. ... Such an extension would deter only police investigation consciously directed toward the discovery of evidence solely for use in a grand jury investigation." 55

\footnotetext{
${ }^{50}$ Elkins v. United States, 364 US 206, 217 (1960).

${ }^{51}$ United States v. Leon, 468 US 897, 918 (1984); Hudson v. Michigan, 547 US 586, 591 (2006); Herring v. United States, 555 US 135 (2009).

${ }^{52}$ See, e.g., Herring v. United States, 555 US 135, 141, 144 (2009).

${ }^{53}$ United States v. Leon, 468 US 897, 907 (1984); Hudson v. Michigan, 547 US 586, 591, 599 (2006); Herring v. United States, 555 US 135, 141 (2009).

${ }^{54}$ See, e.g., United States v. Calandra, 414 US 338, 347 (1974).

${ }^{55} \mathrm{Ibid}$. at 351.
} 
Applying the exclusionary rule in the grand jury and non-criminal contexts would achieve a merely "speculative and undoubtedly minimal advance in the deterrence of police misconduct," and yet it would come at the expense of the ability of the grand jury or civil factfinders to uncover the truth. ${ }^{56}$ Therefore, balancing the costs and benefits has led the Court to deny Fourth Amendment exclusion in these contexts.

A similar balancing exercise has led the Court to allow the introduction of unlawfully obtained evidence to impeach the defendant's credibility. The incremental deterrent benefit in such cases is said to be small: "[T]he deterrent function of the rules excluding unconstitutionally obtained evidence is sufficiently served by denying its use to the government on its direct case. ${ }^{, 57}$ The minimal incremental benefit served by forbidding the use of unlawfully obtained evidence to impeach the defendant is outweighed by the costs of allowing perjured testimony to stand uncorrected and impairing the integrity of the factfinding process. ${ }^{58}$ Accordingly, evidence obtained in violation of the Fourth Amendment, Miranda, or Sixth Amendment can be admitted for purposes of impeaching the defendant's credibility. ${ }^{59}$

Additionally, the Court has limited the group of people who can invoke the Fourth Amendment exclusionary rule. Only those whose Fourth Amendment rights have been violated can ask for exclusion of evidence; the rule cannot be asserted vicariously. The Court justified this limitation in large part by pointing to the significant costs of excluding evidence:

Each time the exclusionary rule is applied it exacts a substantial social cost for the vindication of Fourth Amendment rights. Relevant and reliable evidence is kept from the trier of fact and the search for truth at trial is deflected [...]. Since our cases generally have held that one whose Fourth Amendment rights are violated may successfully suppress evidence obtained in the course of an illegal search and seizure, misgivings as to the benefit of enlarging the class of persons who may invoke that rule are properly considered when deciding whether to expand standing to assert Fourth Amendment violations. ${ }^{60}$

As subsequent sections elaborate, similar standing limitations on exclusion likely apply with respect to other constitutional violations as well, including violations of the Fifth Amendment and the Due Process Clause.

Although the Court has generally extended the Fourth Amendment exclusionary rule to "fruits" of the original violation, it has also placed some limits on how far the "fruit of the poisonous tree" doctrine extends. For example, if the connection

\footnotetext{
${ }^{56} \mathrm{Ibid}$. at $351-52$.

${ }^{57}$ United States v. Havens, 446 US 620, 626 (1980).

${ }^{58}$ Ibid. at 627.

${ }^{59}$ Ibid.; Harris v. New York, 401 US 222, 225-26 (1971); Kansas v. Ventris, 556 US 586, 593-94 (2009).

${ }^{60}$ Rakas v. Illinois, 439 US 128, 137-38 (1978).
} 
between the original violation and the derivative evidence is too attenuated (e.g., if an event has broken the chain of causation between the original illegality and the derivative evidence), then the derivative evidence can be admitted. ${ }^{61}$ Furthermore, if the police would inevitably have discovered the evidence, even absent the constitutional violation, then the exclusionary rule does not apply. ${ }^{62}$ Once again, the Court has justified these restrictions on the exclusionary rule by pointing to the high costs of excluding probative evidence and the limited deterrent effect of excluding evidence that either has been or would have been discovered independently by lawful means. ${ }^{63}$ As discussed in more detail later in the report, these limitations on the fruit of the poisonous tree doctrine likely apply to violations of the Fifth Amendment, Due Process Clause, and the Sixth Amendment. ${ }^{64}$

In more recent Fourth Amendment exclusion cases, the Supreme Court has also considered the availability of alternative sanctions, which may be able to discipline officers at a lesser cost to the administration of justice. ${ }^{65}$ To the extent that such alternative sanctions are viable, exclusion is less likely to be ordered. The Court also examines whether police misconduct is an isolated occurrence or part of a pattern, under the theory that systemic abuses are in greater need of deterrence. ${ }^{66}$ Finally, the Court considers officers' state of mind in committing a violation and reserves discipline only for reckless or deliberate breaches of the law. ${ }^{67}$ Therefore, officers' reasonable, good faith reliance on a warrant, a statute, or a court decision will not give rise to exclusion, even where the warrant is subsequently found to be defective or mistakenly entered into a database after expungement, ${ }^{68}$ the statute is held unconstitutional, ${ }^{69}$ or the court decision is overruled. ${ }^{70}$ On the other hand,

\footnotetext{
${ }^{61}$ Brown v. Illinois, 422 US 590, 603-04 (1975); Murray v. United States, 487 US 533, 537 (1988).

${ }^{62}$ Nix v. Williams, 467 US 431, 444 (1984).

63"If the prosecution can establish by a preponderance of the evidence that the information ultimately or inevitably would have been discovered by lawful means - here the volunteers' search - then the deterrence rationale has so little basis that the evidence should be received. The requirement that the prosecution must prove the absence of bad faith ... wholly fails to take into account the enormous societal cost of excluding truth in the search for truth in the administration of justice." Nix v. Williams, 467 US 431, 444-45 (1984).

${ }^{64}$ When it comes to Miranda violations, evidence derived from the original violation is almost never excluded, for reasons discussed below Part 4.3.

${ }^{65}$ Hudson v. Michigan, 547 US 586, 591, 599 (2006).

${ }^{66}$ Herring v. United States, 555 US 135, 144 (2009).

${ }^{67} \mathrm{Ibid}$. at 144.

${ }^{68}$ United States v. Leon, 468 US 897 (1984); Herring v. United States, 555 US 135, 142 (2009).

${ }^{69}$ Illinois v. Krull, 480 US 340, 349-50 (1987).

${ }^{70}$ Davis v. United States, 564 US 229, 241 (2011).
} 
good faith has not been used to limit exclusion of statements obtained in violation of the Fifth and Sixth Amendment or the Due Process Clause, ${ }^{71}$ but it has limited exclusion under Miranda to some degree. ${ }^{72}$

In general, the exclusionary rule has been weakest and most likely to be subordinated to the interest in truthseeking when it comes to statements obtained in violation of Miranda safeguards. The Court has justified restrictions on exclusion in this setting by noting that Miranda sets out a broad prophylactic rule that sweeps more broadly than the Privilege against Self-Incrimination itself. ${ }^{73}$ Mirandadefective statements are therefore not presumed to be unreliable. ${ }^{74}$ And unlike the admission of coerced statements, the admission of Miranda-defective statements at trial is not considered to be compulsion of a person in direct violation of the Constitution. Furthermore, the Court has held that the benefits of deterring police violation of Miranda are frequently outweighed by the cost of excluding reliable evidence-for example, when Miranda-defective statements are introduced for impeachment, when fruits of Miranda violation are at issue, and when an officer fails to give Miranda warnings based on a reasonable belief that public safety requires him or her to dispense with the warnings. The scope of the Miranda exclusionary rule is considered in greater detail in Sect. 4.3 below.

In brief, the Supreme Court has considered the tradeoff between truthseeking and evidentiary exclusion in a number of cases. In cases where the Constitution does not expressly mandate exclusion, the Court has done a category-by-category analysis of the costs and benefits of the exclusionary rule in deciding whether to impose it. This has created a patchwork of rules that apply differently depending on the rule that is violated, the nature of the evidence being considered, and the use to which the evidence would be put at trial.

\subsection{Social Relevance of Truth and Individual Rights in Criminal Trials}

\subsubsection{Relevance of Determining the Truth}

As discussed in Sect. 3.1, the goal of seeking truth in criminal cases is not expressly mentioned in the U.S. Constitution or criminal procedure codes. Nonetheless, numerous court decisions mention it as a guiding principle. The search for truth is considered important for the effective enforcement of the criminal law and for the

\footnotetext{
${ }^{71}$ See below Parts 4.1-4.2.

${ }^{72}$ See below Part 4.3 (discussing public safety exception to Miranda, as well as the relevance of good faith to exclusion of statements derived from earlier Miranda-defective statements).

${ }^{73}$ See, e.g., United States v. Patane, 542 US 630, 639 (2004).

${ }^{74}$ See, e.g., Mincey v. Arizona, 437 US 385, 397-98 (1978) (involuntary confession cannot be used even for impeachment purposes as it is more likely to be unreliable and the police action in question is more outrageous and therefore in greater need of discipline).
} 
pursuit of justice more generally. As DNA testing has revealed a high incidence of wrongful convictions, reliable factfinding has become a topic of public discussion and concern. There is growing recognition that the public legitimacy of the criminal justice system depends at least in part on the ability of the system to attain accurate outcomes.

\subsubsection{Presentation of Factfinding to the Public}

To increase the transparency and reliability of factfinding, a number of U.S. jurisdictions have recently taken measures to record critical stages of the criminal process. Police departments are increasingly recording police-citizen interactions on the street, custodial interrogations, and identification procedures. Some courts are in turn allowing the recording and even broadcasting of trial proceedings. Beyond improving reliability, such recording is regarded as helping to improve the fairness and public legitimacy of the proceedings.

Recording of interrogations is seen as particularly useful in preventing involuntary and false confessions. It is said to reduce the risk that police would use coercive tactics to obtain statements, to provide a more transparent record for courts to evaluate the voluntariness and reliability of confessions, and to offer a more accurate and thorough transcription of the defendant's statements for use at trial. ${ }^{75}$ For all these reasons, a growing number of U.S. jurisdictions now require the recording of interrogations. ${ }^{76}$

While police officers were initially concerned that taping would reduce suspects' willingness to confess, early evidence from jurisdictions that have adopted taping policies suggests that the risk of lost confessions is not significant. While one early study reported that suspects were less willing to talk when they knew they were being recorded, ${ }^{77}$ more recent research has found no decrease in confessions that can be attributed to the taping of interrogations. ${ }^{78}$ Even the study that found a small drop in confessions also reported incidental benefits of recording, such as "better preparation by detectives and better monitoring of detectives' work by supervisors." 79

Police-citizen interactions outside the police station are also increasingly being recorded on body or dashboard cameras employed by police officers. ${ }^{80}$ Public discussion has emphasized how recording of these interactions can help reduce police violence, as well as unwarranted complaints against police. Recording also helps preserve evidence for use in subsequent prosecution and thus contributes to the search for truth. On the other hand, without careful regulation, recording may

\footnotetext{
${ }^{75}$ Fisher/Rosen-Zvi, 2008 at 888.

${ }^{76}$ Taslitz, 2012 at 409 (acknowledging trend but adding that "the vast majority of police departments still do not record" interrogations).

${ }^{77} \mathrm{Ibid}$.

${ }^{78}$ Leo, 2008 at 303.

${ }^{79}$ Miller/Wright, 2007 at 643 (citing Geller, 1993).

${ }^{80}$ Miller et al., 2014.
} 
interfere with the privacy interests of citizens captured on camera. The cost of recording, storing, and reviewing the massive amounts of data is also a serious concern weighing against the broad use of body cameras. ${ }^{81}$

When it comes to the recording and broadcasting of trials, rules vary significantly from jurisdiction to jurisdiction. Some U.S. jurisdictions categorically ban televising trials, others expressly permit it, while yet others have no specific rules and leave the decision to the discretion of the court. For example, Federal Rule of Criminal Procedure 53 prohibits the broadcasting of judicial proceedings in criminal cases. Courts have upheld the constitutionality of the rule against First Amendment challenges. ${ }^{82}$ Florida permits the broadcasting of all trials, including criminal trials, under guidelines to ensure the fair administration of justice. ${ }^{83}$ In Texas, no specific rule governs the broadcasting of criminal trials, but trial courts have occasionally permitted such broadcasting based on their own discretion to control the conduct of the proceedings. ${ }^{84}$ The propriety of the judge's orders is then analysed for its consistency with the Due Process Clause.

The televising of trials affects a number of interests, which may at times be in conflict with one another: the fair trial of the defendant, witness rights, First Amendment rights of the media, and the interests in judicial integrity and efficiency. The U.S. Supreme Court, in Chandler v. Florida, held that broadcasting of criminal trials might in some circumstances violate the Due Process Clause but that it does not inherently do so. To mount a successful Due Process challenge, a defendant must show that broadcasting in his specific case is likely to adversely impact the fairness of his trial. The defendant may succeed in his challenge if he demonstrates that coverage would compromise the ability of the jury to judge him fairly or would adversely affect the participants in his trial to such a degree as to constitute a denial of due process.

Some state rules also attempt to address other concerns raised by televising trials. For example, California rules on televising trials lay out certain requirements concerning the type of equipment to be used to minimize disruption of the proceedings. ${ }^{85}$ California courts also often prohibit the broadcasting of witness testimony to prevent concerns about the safety of witnesses and their willingness to testify. ${ }^{86}$ Other rules balance such interests against First Amendment rights to broadcast trials of public significance. ${ }^{87}$

\footnotetext{
${ }^{81} \mathrm{Ibid}$.

${ }^{82}$ See, e.g., United States v. Moussaoui, 205 FRD 183, 185 (2002); United States v. Edwards, 785 F 2d 1293, 1295-96 (5th Cir. 1986).

${ }^{83}$ Florida Rules of Judicial Administration, Rule 2.450. Broadcasting was first regulated by the Florida Supreme Court in In re Petition of Post-Newsweek Stations Fla., Inc., 370 So 2d 764 (Fla. 1979) (laying out standards for broadcasting of criminal trials).

${ }^{84}$ See, e.g., Wright v. State, 374 SW 3d 564 (Tex.App.-Houston [14 Dist.], 2012).

${ }^{85} 2013$ California Rules of Court Rule 1.150 (e)(8).

${ }^{86}$ See, e.g., KFMB-TV Channel 8 v. Municipal Court, 221 Cal App 3d 1362, 1364 (Cal. App. 4 Dist. 1990); Judicial Council of California, Administrative Office of the Courts, 2007 at 2-3.

${ }^{87}$ In re Petition of Post-Newsweek Stations Fla., Inc., 370 So 2d 764 (Fla. 1979).
} 
In summary, while recording of interrogations and police-citizen interactions is broadly advocated and increasingly adopted by U.S. states and localities, televising trials is not regarded as critical to improving the accuracy and fairness of the criminal process. Indeed, it is sometimes said to conflict with these goals, as when a witness is discouraged from testifying truthfully or when broadcasting prejudices or distracts the jury. Accordingly, policymakers and commentators have been less ardent about introducing the broadcasting of trials than about the recording of interrogations and other citizen-police interactions.

\subsubsection{Public Discussion of Miscarriages of Justice}

In the 1990s, DNA testing became more broadly available and led to the first exonerations of wrongfully convicted individuals. The Innocence Project, founded initially at Cardozo Law School, helped numerous defendants obtain DNA testing and prove their innocence. Over the years, the Innocence Project transformed into a nationwide movement, which included Innocence clinics at law schools across the country, Conviction Integrity Units within prosecutor's offices, and Innocence Review Commissions. The work of the Innocence Movement has given rise to broad public discussion of miscarriages of justice, and the problem of wrongful convictions has been highlighted in popular culture, TV shows, movies, and books. ${ }^{88}$

Most relevant to this report, the Innocence Movement has shed light on the problem of unreliable confessions. The Innocence Project has reported that $27 \%$ of the first 325 wrongful convictions were based at least in part on a false confession. Another study of wrongful convictions, by Brandon Garrett, found that forty of the first 250 people exonerated through DNA (16\%) made a false confession. ${ }^{89}$ Garrett closely examined the features of the false confessions in these cases and found several common elements. First, almost all of these confessions were quite detailed and contained information about the crime that only the true suspect and the investigating officers could have known. ${ }^{90}$ Given the subsequent exoneration of the defendants, the only plausible explanation for these confessions is that the police, whether intentionally or accidentally, fed information about the crime to the suspect. Moreover, psychological coercion, including trickery, was brought to bear on the suspects to force them to confess to a crime they did not commit. Notably, a high number of the innocent defendants who confessed were mentally retarded, mentally ill, or juveniles, making them particularly susceptible to psychological

\footnotetext{
${ }^{88}$ Garrett, 2012 at 6.

${ }^{89} \mathrm{Ibid}$. at 18.

${ }^{90} \mathrm{Ibid}$. at $19-20$.
} 
pressure. ${ }^{91}$ Another remarkable fact is that in the majority of the false confession cases, the interrogations were partially recorded, whether by audio or video. ${ }^{92}$ But the recordings typically included only the final confession, not what came before. ${ }^{93}$ Finally, in a number of the cases, police stopped investigating once they obtained a confession, which meant that they failed to unearth critical inconsistencies in the evidence. $^{94}$

Public discussion of the sources of wrongful convictions, including contaminated and coerced confessions, has led to calls for reform across the country. Most notably, as discussed in the previous Section, it has encouraged a number of jurisdictions to introduce mandatory recording of interrogations in order to reduce the risk of unreliable confessions. ${ }^{95}$

\section{Constitutional Limitations on the Admissibility of Confessions in Criminal Proceedings}

\subsection{Fifth and Fourteenth Amendment Limits on Admissibility of Confessions}

Confessions in the United States were originally regulated exclusively by common law. Under the common law, two principles prohibited the admission of coerced confessions. The "nemo tenetur" principle prohibited the use of torture and coercion by government agents to force individuals to incriminate themselves. ${ }^{96}$ The voluntariness doctrine prohibited the use of involuntary confessions because such confessions were presumed to be unreliable. ${ }^{97}$

In 1897, the Supreme Court for the first time relied on the Constitution to exclude a statement in Bram v. United States. It held that the common-law rule banning the admission of involuntary confessions was "embedded in the Fifth Amendment" Privilege against Self-Incrimination and that the privilege thus precluded the admission of compelled statements. ${ }^{98}$ This new constitutional rule applied only in federal court, however, as the Supreme Court had not yet applied the Fifth Amendment to the states. ${ }^{99}$ As a result, for a long time, the Fifth

\footnotetext{
${ }^{91}$ Ibid. at 21.

${ }^{92}$ Ibid. at 32 .

${ }^{93}$ Ibid.

${ }^{94}$ Ibid. at 35 .

${ }^{95}$ See above Part 3.4.2.

${ }^{96}$ Tomkovicz, 2011 at 64; Godsey, 2005 at 479-80.

${ }^{97}$ Hopt v. Utah, 110 US 574 (1884); Tomkovicz, 2011 at 64; Godsey, 2005 at 482.

${ }^{98}$ Bram v. United States, 168 US 532, 548 (1897).

${ }^{99}$ Twining v. New Jersey, 211 US 78 (1908). The Fifth Amendment was first applied to the states in Malloy v. Hogan, 378 US 1 (1964).
} 
Amendment rule did not have a broad impact, as the vast majority of criminal cases were brought at the state level.

The first time that the Supreme Court held that a confession obtained by state officials was unconstitutional was in 1936, in Brown v. Mississippi. ${ }^{100}$ The use of physical violence to extract confessions was "widespread throughout the country" at the time. ${ }^{101}$ In Brown, the confessions were obtained through particularly heinous and brutal acts - repeated mock lynching, beatings, and other degrading treatment. The Court held that the methods used to obtain confessions were "revolting to the sense of justice."102 Accordingly, using the coerced confessions as evidence at trial was "a clear denial of due process" and a violation of the Constitution. ${ }^{103}$

In the following three decades, the Court continued to rely on the Due Process Clause to evaluate the admissibility of confessions obtained through coercive methods. In 1964, the Court explained that the Fifth Amendment Privilege against Self-Incrimination likewise prohibited coerced confessions and that the standards for evaluating extrajudicial confessions under the Due Process Clause and the privilege were identical. ${ }^{104}$ In deciding whether a confession is coerced under these provisions, the Court applies a totality of circumstances test to determine whether the confession was voluntarily given. The Court examines the personal characteristics of the accused (education level, age, mental state, etc.), ${ }^{105}$ as well as physical or psychological coercion applied by the authorities. ${ }^{106}$ Physical coercion includes violence as well as food or sleep deprivation, ${ }^{107}$ while psychological pressure includes threats, humiliation, isolation, trickery, and prolonged interrogation. ${ }^{108}$ The critical question is whether official pressure has overborne the will of the suspect, preventing him from making a rational decision whether to confess.

In the early cases suppressing involuntary confessions, the Court emphasized the need to condemn the coercion at issue and the concern that coerced confession are unreliable. It further held that the admission of coerced confessions violated the U.S. criminal justice system's commitment to "fair state-individual balance [that requires] the government to leave the individual alone ... [and] to shoulder the entire load." ${ }^{109}$

\footnotetext{
${ }^{100} 297$ US 278 (1936).

${ }^{101}$ National Comm'n on Law Observance and Enforcement, 'Report on Lawlessness in Law-Enforcement' 1931, 3, cited in Miller/Wright, 2007 at 518.

${ }^{102}$ Brown v. Mississippi, 297 US 278, 286 (1936).

${ }^{103}$ Ibid.

${ }^{104}$ Murphy v. Waterfront Comm'n of New York Harbor, 378 US 52, 79-80 (1964).

${ }^{105}$ E.g., Payne v. Arkansas, 356 US 560, 567 (1958); Culombe v. Connecticut, 367 US 568, 620 (1961).

${ }^{106}$ E.g., Payne v. Arkansas, 356 US 560, 567 (1958); Ashcraft v. Tennessee, 322 US 143, 153-54 (1944); Spano v. New York, 360 US 315, 323 (1959).

${ }^{107}$ E.g., Payne v. Arkansas, 356 US 560, 567 (1958); Ashcraft v. Tennessee, 322 US 143, 167 (1944).

${ }^{108}$ E.g., Spano v. New York, 360 US 315, 322-23 (1959); Arizona v. Fulminante, 499 US 279, 288 (1991).

${ }^{109}$ Murphy v. Waterfront Comm'n of New York Harbor, 378 US 52, 55 (1964).
} 
Over time, disapproval of offensive police tactics, rather than reliability, became the dominant reason for excluding coerced confessions. ${ }^{110}$ In 1959, the Court stated that "[t]he abhorrence of society to the use of involuntary confessions does not turn alone on their inherent untrustworthiness. It also turns on the deep-rooted feeling that the police must obey the law while enforcing the law." ${ }^{\text {111 }}$ By 1986, the Court held that the existence of police coercion is a prerequisite for a finding that a confession is constitutionally invalid. ${ }^{112}$ Thus a confession cannot be considered coerced in violation of the Due Process Clause or the privilege where a suspect faces absolutely no government influence and responds to his own "command hallucinations." "I13 Likewise, coercion by a private party does not violate the Constitution: "If a relative of a crime victim were to torture a person until he admitted his guilt, neither constitutional guarantee would bar that confession [although an evidentiary rule focused on reliability might]." Suppression under the Fifth and Fourteenth Amendment is therefore justified primarily as necessary to condemn and deter future police conduct. Concerns about the reliability of the evidence are resolved by state evidentiary rules, not through constitutional interpretation. $^{114}$

By 1967, physical brutality had largely vanished from interrogation rooms. This was in part the result of judicial scrutiny of confessions, in part a product of the increasing professionalization of police, and in part a response to broad public outrage at revelations of third-degree tactics. ${ }^{115}$ Yet while physical violence during interrogations was a rare occurrence by the late 1960s, the police applied other types of pressure to extract confessions: denial of food or sleep, protracted interrogations, isolation, and various psychological ploys, including trickery. ${ }^{116}$

Some commentators have criticized the voluntariness test for failing to address adequately these more subtle, yet nonetheless coercive tactics. Part of the difficulty is that judges have to resolve, without a reliable record, competing claims of what

\footnotetext{
${ }^{110}$ Kamisar, 1995 at 939.

${ }^{111}$ Spano v. New York, 360 US 315, 320 (1959).

${ }^{112}$ Colorado v. Connelly, 479 US 157, 167 (1986).

${ }^{113} \mathrm{Ibid}$. at $161,167$.

${ }^{114}$ Ibid. at 159.

${ }^{115}$ Miller/Wright, 2007 at 521-22; Cassell, 1996 at 474-75.

${ }^{116}$ Miranda v. Arizona, 384 US 436, 447, 448 (1966). Interviews with two Texas defense attorneys and two prosecutors suggest that although physical coercion is a thing of the past, psychological tactics - especially lying to suspects about the evidence in the case - continue to be commonly used. As the defense attorneys interviewed suggested, such tactics, particularly when used with vulnerable (e.g., young or cognitively impaired) suspects, can result in false confessions. Interview with Texas Prosecutor \#1, by Jenia I. Turner, July 20, 2016, Dallas, Texas; Interview with Texas Prosecutor \#2, by Jenia I. Turner, July 27, 2016, Dallas, Texas; Interview with Texas Defense Attorney \#1, by Jenia I. Turner, August 8, 2016, Dallas, Texas; Interview with Texas Defense Attorney \#2, by Jenia I. Turner, September 20, 2016, Dallas, Texas.
} 
transpired in the interrogation room. Although the state bears the burden of proof to show admissibility, in practice, courts frequently credit police accounts of the interrogation over inconsistent accounts by the defendant. ${ }^{117}$ In addition, the voluntariness test has been criticized as too malleable and unpredictable, as it relies on many different factors to determine whether a confession was involuntary. ${ }^{118}$

While courts and commentators have debated the voluntariness test and its effectiveness, the exclusion of statements found to be involuntary has not been contested. Courts have maintained a robust exclusionary rule, which applies to the coerced confession and to evidence derived from it. Coerced statements cannot be used by the prosecution for any purpose at trial-not even to impeach the defendant's credibility. Nor can coerced statements be admitted under a good-faith or public safety exception. ${ }^{119}$ This means that even a "ticking bomb" scenario, under which a government agent coerces a suspect to obtain evidence that he believes would save many lives, would not permit the subsequent admission of statements coerced from a suspect.

Fruits of a coerced confession are also generally excluded, under the theory that such exclusion is necessary to deter police misconduct more effectively. ${ }^{120}$ But there are some limits on the fruits doctrine with respect to coerced statements. The prosecution may be able to introduce evidence derived from coerced confession if the government can show that it obtained the same evidence through an independent source, or that it would have inevitably obtained it from an independent source. ${ }^{121}$ Additionally, the prosecution may be able to introduce fruits of the initial involuntary statement if it can show that the taint of the initial violation was attenuated. ${ }^{122}$ In other words, as time passes and circumstances change, the effect of the initial coercion may dissipate to the point that a subsequent statement or other evidence can no longer be considered to be tainted by the coercion. ${ }^{123}$

Finally, if the prosecution can show that the coerced confession is reliable, it may be able to introduce the confession itself in evidence against a third party who

\footnotetext{
${ }^{117}$ See, e.g., Pepson/Sharifi, 2010 at 1228-29.

${ }^{118}$ See, e.g., Saltzburg/Capra, 2014 at $717-18$.

${ }^{119}$ Mincey v. Arizona, 437 US 385, 397-98 (1978); New York v. Quarles, 467 US 649, 654 (1984) (clarifying that "we have before us no claim that respondent's statements were actually compelled by police conduct which overcame his will to resist").

${ }^{120}$ Cammack, 2013 at 23.

${ }^{121}$ See, e.g., Kastigar v. United States, 406 US 441, 460 (1972); Nix v. Williams, 467 US 431 (1984).

${ }^{122}$ See, e.g., Broun, $2013 \S 159$ at 875; Oregon v. Elstad, 470 US 298, 310 (1985).

${ }^{123}$ Tomkovicz, 2011 at 89.
} 
was not subject to coercion. ${ }^{124}$ Both the Due Process and Fifth Amendment privilege are considered personal rights, so a third party would not have "standing" to challenge the coercion of another person. ${ }^{125}$

\subsection{Sixth Amendment Limits on Admissibility of Confessions}

Because of concerns about the effectiveness of the voluntariness test, in 1964, the Supreme Court began relying on the Sixth Amendment right to counsel as a safeguard against coerced confessions. In Massiah v. United States, the Court invalidated a confession obtained by a government informant after the defendant had been charged and obtained counsel. ${ }^{126}$ It held that once a person is formally charged, he is entitled to the assistance of counsel whenever government agents deliberately elicit any incriminating statements from him. ${ }^{127}$ The Court suggested that if an indicted defendant is denied counsel during pretrial proceedings, he is effectively denied "effective representation by counsel at the only stage when legal aid and advice would help him." ${ }^{\text {"128 }}$ In a more recent case, the Supreme Court explained that the right to counsel is extended to pretrial "deliberate elicitations" to ensure that the trial right to counsel is not "render[ed] ... entirely impotent" by the pretrial interrogation. ${ }^{129}$ If the government breaches the right to counsel by eliciting statements from an indicted defendant, any statements obtained in the process will be excluded from evidence at trial. ${ }^{130}$

The extension of the Sixth Amendment right to counsel to the pretrial stage, and the use of exclusion to enforce it, generated heated debate among the Justices in Massiah. The dissenters were concerned about the barring of "relevant, reliable and highly probative" evidence. ${ }^{131}$ As the dissenting Justices noted, "Without the evidence, the quest for truth may be seriously impeded and in many cases the trial court, although aware of proof showing defendant's guilt, must nevertheless release him because the crucial evidence is deemed inadmissible." ${ }^{132}$ Because Massiah's statements were not coerced and communications between counsel and client were

\footnotetext{
${ }^{124}$ See Fisher v. United States, 425 US 391, 397-98 (1976); see also People v. Badgett, 10 Cal 4th 330, 343, 895 P 2d 877 (1995).

${ }^{125}$ Fisher v. United States, 425 US 391, 397-98 (1976); Tomkovicz, 2011 at 94-95.

${ }^{126} 377$ US 201 (1964).

${ }^{127} \mathrm{Ibid}$. at 206.

${ }^{128}$ Ibid. at 204 (quoting Spano v. New York, 360 US 315, 326 (1959) (Justice Douglas, concurring)).

${ }^{129}$ Kansas v. Ventris, 556 US 586, 591 (2009).

${ }^{130}$ Massiah v. United States, 377 US 201, 207 (1964).

${ }^{131}$ Ibid. at 208 (Justice White, dissenting).

${ }^{132}$ Ibid.
} 
in no way disturbed, the extension of the exclusionary rule to statements elicited by government agents after formal charges appeared unwarranted to the dissent. ${ }^{133}$

More recently, a majority of Supreme Court justices have revived the idea that the Sixth Amendment ban on deliberate elicitations and the exclusionary rule that enforce it sweep too broadly. The Court has made it easier for defendants to waive their pretrial right to counsel ${ }^{134}$ and has carved out exceptions to the Sixth Amendment exclusionary rule. ${ }^{135}$ In Kansas v. Ventris, the Court held that statements obtained in violation of the pretrial right to counsel may be used to impeach the defendant's credibility if he testifies at trial in a manner inconsistent with those statements. ${ }^{136}$ The Court reasoned that the exclusionary rule in this context protects the core Sixth Amendment right - to have counsel's assistance at trial —only indirectly. Exclusion is not expressly mandated by the Constitution. Moreover, the rule's purpose is primarily deterrent - to prevent future violations, rather than to remedy a violation that has already occurred at the pretrial stage and cannot be undone. ${ }^{137}$ Conducting a balancing analysis, the Court concluded that any deterrent benefit served by extending the exclusionary rule to cover the use of evidence for impeachment purposes is outweighed by the interest in protecting the integrity of the trial against false statements. Following a similar cost-benefit analysis, some lower courts have further limited the Sixth Amendment exclusionary rule and admitted the fruits of statements obtained in violation of the Sixth Amendment. ${ }^{138}$

The Supreme Court has yet to clarify the precise scope of the Sixth Amendment exclusionary rule. Given the cost-benefit analysis the Court used in Ventris, however, we are likely to see a further narrowing of this exclusionary rule, as we have seen with the Fourth Amendment and the Miranda exclusionary rule (the subject of the next Section). Like evidence obtained in violation of the Fourth Amendment and Miranda, but unlike confessions coerced in violation of the Due Process Clause and the Privilege against Self-Incrimination, statements elicited in contravention of the Sixth Amendment are presumed to be reliable and probative evidence; "[t]he fact that an accused lacked legal assistance when he made inculpatory statements in response to noncoercive official inducements does not raise serious questions about the accuracy of those statements." ${ }^{\text {139 }}$ Because exclusion of such statements is not expressly mandated by the Constitution and stands in the way of accurate factfinding, it is likely to be imposed more sparingly by the current Supreme Court,

\footnotetext{
${ }^{133} \mathrm{Ibid}$. at $208-10$.

${ }^{134}$ Montejo v. Louisiana, 556 US 778, 786 (2009).

${ }^{135}$ Nix v. Williams, 467 US 431 (1984); Michigan v. Harvey, 494 US 344 (1990); Kansas v. Ventris, 556 US 586 (2009).

${ }^{136} 556$ US 586, 593-94 (2009).

${ }^{137}$ Ibid. at 593 .

${ }^{138}$ See, e.g., United States v. Fellers, 397 F 3d 1090 (8th Cir. 2005).

${ }^{139}$ Tomkovicz, 2012 at 48 ("There is nothing about the governmental conduct that is the concern of Massiah-deliberate elicitation of admissions from an uncounseled defendant-that casts doubt upon the reliability of statements made or the fruits of those statements.").
} 
which is both more textualist in its interpretation of the Constitution and more hostile to remedies that impede the search for truth in criminal cases. ${ }^{140}$

\subsection{The Miranda Safeguards Against Coerced Confessions}

Sixth Amendment protections are limited to citizen-police interactions that occur after the filing of formal charges. As a result, the Sixth Amendment does not apply to most police interrogations, which occur earlier in the process. ${ }^{141}$ This helps explain why, even after the Supreme Court had decided Massiah and established Sixth Amendment protections during certain pretrial encounters between police and suspects, it remained concerned that police interrogations were not sufficiently regulated. A majority of the Justices believed that pretrial interrogations - as a result of their isolated and non-transparent setting-harbored the risk that police would use physical or psychological pressure to compel suspects to confess.

To minimize this risk of compelled statements, in 1966, in Miranda v. Arizona, the Court established new safeguards for custodial interrogations. It held that whenever police interrogate a suspect who is in custody, they must warn him that he has the right to remain silent, that anything he says may be used in evidence against him, that he has the right to the presence of an attorney, and that if he cannot afford an attorney, one will be appointed for him. If the suspect asserts his right to remain silent, the police must honor that right and cease questioning, although they can resume questioning after a "cooling off" period and after taking measures (such as providing a new set of Miranda warnings) to ensure that the subsequent interrogation is free of coercion. ${ }^{142}$

When a suspect invokes his right to counsel, police must again stop interrogation and are forbidden from initiating any further questioning. ${ }^{143}$ As the Court explained in Edwards v. Arizona, "additional safeguards are necessary when the accused asks for counsel [as opposed to invoking only the right to remain silent]." ${ }^{144}$ This is because the request for counsel indicates that the suspect does not feel capable to face the pressures of interrogations on his own, so the need for protection appears stronger.

While police must stop questioning once the suspect has asked for an attorney, they do not need to provide an attorney to him at the stationhouse. Indigent suspects typically have a lawyer appointed for them - and meet their lawyer for the first time - at their initial arraignment before a magistrate, which must occur within 48 hours of arrest.

\footnotetext{
${ }^{140}$ Ibid. at $48-49$.

${ }^{141}$ Moran v. Burbine, 475 US 412, 428-32 (1986).

${ }^{142}$ Michigan v. Mosley, 423 US 96, 106-07 (1975).

${ }^{143}$ Edwards v. Arizona, 451 US 477, 484-85 (1981). A sufficiently long break in custody, however, allows the police to reapproach the subject and attempt to interrogate him anew, after giving a fresh set of Miranda warnings. Maryland v. Shatzer, 559 US 98, 104 (2010). Likewise, the suspect may himself reinitiate contact with the authorities, in which case they may resume the interrogation and obtain a valid waiver of Miranda rights.

${ }^{144}$ Edwards v. Arizona, 451 US 477, 484 (1981).
} 
Miranda therefore assures them that suspects would not be further interrogated by the police until they have an attorney present with them-not that counsel will be made available to them immediately upon request (in practice, once an attorney is present, she advises her client not to say anything in response to police questioning, so police do not in fact conduct further interrogations of the suspect once counsel is present).

If the police fail to follow the Miranda rules, any resulting statement will be excluded from trial. ${ }^{145}$ Moreover, the prosecution is prohibited from commenting to the jury about the silence of the defendant during a custodial interrogation, or about the defendant's decision to invoke his Miranda rights. ${ }^{146}$

The suspect may waive his right to remain silent and his right to the presence of an attorney. The government must prove that the suspect did so knowingly, voluntarily, and intelligently. ${ }^{147}$ Statements made after a waiver are admissible into evidence. However, the suspect can reassert his right to remain silent or his right to an attorney at any point during the interrogation, and the police must honor that invocation. ${ }^{148}$ The Court's ruling on waivers has been criticized by many, including the dissenters in Miranda. Critics note that police officers who might coerce a confession might similarly coerce a waiver, and the warnings do little to reduce that likelihood. ${ }^{149}$

When Miranda was decided, it was greeted with hostility by many in law enforcement and in Congress. In fact, just two years after the decision was handed down, Congress passed a statute that re-imposed the totality-of-circumstances voluntariness test for evaluating confessions in federal court; under that standard, Miranda warnings were optional. ${ }^{150}$ Federal prosecutors ignored the statute, however, as they doubted its constitutionality. When the law was finally challenged in the courts in 2000, the Supreme Court struck it down as incompatible with Miranda. ${ }^{151}$

Some critics of Miranda have complained that it has stifled efforts to reform the law governing confessions in the United States:

The Miranda decision has petrified the law of pre-trial interrogation for the past twenty years, foreclosing the possibility of developing and implementing alternatives that would be of greater effectiveness both in protecting the public from crime and in ensuring fair treatment of persons suspected of crime. ... Nothing is likely to change in the future as long as Miranda remains in effect and perpetuates a perceived risk of invalidation for any alternative system that departs from it. ${ }^{152}$

\footnotetext{
${ }^{145}$ As subsequent discussion elaborates, the statement may be used to impeach the defendant, if he testifies at trial.

${ }^{146}$ See, e.g., Miranda v. Arizona, 384 US 436, 468 n. 37 (1966).

${ }^{147}$ Ibid. at $444-45$.

${ }^{148}$ Ibid.

${ }^{149}$ See, e.g., ibid. at 505 (Justice Harlan, dissenting) ("The new rules are not designed to guard against police brutality or other unmistakably banned forms of coercion. Those who use third-degree tactics and deny them in court are equally able and destined to lie as skillfully about warnings and waivers.").

${ }^{150} 18$ USC $\S 3501$.

${ }^{151}$ Dickerson v. United States, 530 US 428, 443 (2000).

${ }^{152}$ Cassell, 1996 at 498 (citing Office of Legal Policy, 1989 at 437).
} 
Contrary to this prediction, however, recent years have seen a steady increase in jurisdictions that have adopted policies and laws requiring audio- or video-recording of interrogations. ${ }^{153}$ Such recording is mandated in addition to, rather than as an alternative to, Miranda warnings, and is therefore consistent with federal constitutional requirements.

While legislative efforts have largely focused on supplementing Miranda rules, the Supreme Court has itself gradually reduced the scope of Miranda protections. The first way in which this weakening has occurred is the definition of custody. Miranda only applies to defendants who are in custody, because the Court has held that it is only then that the police-dominated atmosphere and isolation leads to the type of compulsion that the Fifth Amendment prohibits. But over time, the Court has explained that not every interrogation at a police station is necessarily custodial. For example, a suspect is not in custody if he comes to the station voluntarily and is told that he is free to leave. ${ }^{154}$ Likewise, an ordinary traffic stop is not considered custodial for purposes of Miranda protections. ${ }^{155}$

Over time, the Court has also made it more difficult for suspects to invoke their Miranda rights and easier to waive those rights. While Miranda suggested that the government bears a "heavy burden" to show that a suspect has knowingly, voluntarily, and intelligently waived his rights, more recent cases have suggested that the burden is not that difficult to meet. For example, the suspect need not be told of the scope of investigation and need not be told that an attorney was trying to reach him. ${ }^{156}$ Essentially, for a waiver to be knowing, all that the suspect must understand is the meaning of the Miranda warnings themselves. Recent cases have further expanded the ability of suspects to provide implied - and therefore potentially unintentional-waivers. Thus a suspect who remained silent in the face of prolonged questioning was found to have waived his rights because he spoke English, showed no signs of mental disability, and ultimately, after several hours of questioning by the police, provided answers to a few questions. ${ }^{157}$

At the same time that it has loosened the standard for valid Miranda waivers, the Court has tightened the requirements for invoking Miranda rights. It has held that for Miranda protections to attach, the suspect must invoke his rights in a clear and

\footnotetext{
${ }^{153}$ For example, of statutory regulation, see 725 Illinois Compiled Statutes 5, Section 103-2.1; Texas Code of Criminal Procedure article 38.22. For example, of judicial regulation, see Stephan v. State, 711 P 2d 1156 (Alaska 1985); State v. Scales, 518 NW 2d 587, 592 (Minnesota 1994). The Innocence Project reports that " 24 states, from North Carolina to Massachusetts to Illinois, require the recording of custodial interrogations through law or court action. More than a thousand additional law enforcement agencies voluntarily record interrogations." Innocence Project, 2017; see also Sullivan, 2014. The Department of Justice has also announced a policy that establishes a presumption in favor of recording of custodial interrogations. Memorandum from James M. Cole, 2014 at 2.

${ }^{154}$ California v. Beheler, 463 US 1121, 1123-24 (1983); Oregon v. Mathiason, 429 US 492, 495 (1977).

${ }^{155}$ Berkemer v. McCarty, 468 US 420, 439-41 (1984).

${ }^{156}$ Moran v. Burbine, 475 US 412, 422-23 (1986).

${ }^{157}$ Berghuis v. Thompkins, 560 US 370, 385-86 (2010).
} 
unequivocal fashion. If the assertion is ambiguous or hesitant at all, police are free to proceed with their questions. ${ }^{158}$ Under this jurisprudence, only the confident or legally well-educated suspects can properly invoke their Miranda rights.

The Supreme Court has also gradually shrunk the scope of Miranda's exclusionary rule. The Miranda decision itself did not spend much time justifying the need to exclude evidence to remedy Miranda violations. Because a violation of Miranda was presumed to be a violation of the Privilege against Self-Incrimination, the admission of Miranda-defective statements into evidence was thought to be itself a compulsion banned by the Fifth Amendment. ${ }^{159}$

Just five years later, however, in Harris v. New York, the Court held that the prosecution may introduce Miranda-defective statements at trial to impeach the credibility of the defendant if he testifies in a manner inconsistent with those statements. ${ }^{160}$ The Court justified this exception in part by noting the importance of impeachment as a "traditional truth-testing device[] of the adversary process." ${ }^{161}$ It further stated that exclusion of Miranda-defective statements is not always required because a violation of Miranda is not necessarily a violation of the Fifth Amendment. ${ }^{162}$ The Court suggested that exclusion under Miranda should be examined separately from the underlying Fifth Amendment right and should be imposed only when it is necessary to deter police misconduct in obtaining confessions. ${ }^{163}$

In several subsequent cases, the Court reaffirmed the idea that Miranda is a "mere" prophylactic device that sweeps more broadly than the Privilege against Self-Incrimination itself. Because of this, Miranda exclusion is generally limited only to those cases where the need to deter police misconduct is greatest and outweighs the interest in admitting probative statements into evidence. Accordingly, while Miranda-defective statements themselves must be suppressed from trial, evidence derived from these statements can generally be used. ${ }^{164}$

For similar reasons, the Court has also carved out a public safety exception to the Miranda exclusionary rule. A statement obtained without proper warnings may nonetheless be admissible if police reasonably believed that a threat to public safety

\footnotetext{
${ }^{158}$ Davis v. United States, 512 US 452, 459 (1994); Berghuis v. Thompkins, 560 US 370, 381 (2010).

${ }^{159}$ See, e.g., Miranda v. Arizona, 384 US 436, 439, 461-62, 479, 490-91 (1966).

${ }^{160} 401$ US 222, 225-26 (1971).

${ }^{161}$ Ibid. at 225 .

${ }^{162}$ Ibid. at 224. The Court points out that "[p]etitioner makes no claim that the statements made to the police were coerced or involuntary" and then later suggests that interrogations that violate Miranda may nonetheless produce trustworthy statements.

${ }^{163}$ See ibid. at 225 ("Assuming that the exclusionary rule has a deterrent effect on proscribed police conduct, sufficient deterrence flows when the evidence in question is made unavailable to the prosecution in its case in chief.").

${ }^{164}$ Michigan v. Tucker, 417 US 433, 449 (1974); United States v. Patane, 542 US 630, 643-44 (2004). The one situation in which the fruits of a Miranda violation may be inadmissible is when a suspect first provides a statement in the absence of Miranda warnings and then makes a subsequent confession after warnings are properly given. The second confession may be inadmissible, particularly if officers act in bad faith. Missouri v. Seibert, 542 US 600, 615-17 (2004).
} 
required them to interrogate the suspect swiftly and without giving Miranda warnings. ${ }^{165}$ Therefore, if police need to quickly obtain information about a hidden weapon, an explosive device, or a dangerous associate of the suspect who is on the loose, they may be permitted to question the suspect about those subjects without first giving Miranda warnings. ${ }^{166}$

At bottom, the narrowing of the Miranda exclusionary rule has been motivated by a belief that Miranda protections are not expressly required by the Constitution, that Miranda-defective statements are reliable, and that the Miranda exclusionary rule interferes too greatly with the search for truth and the effective enforcement of criminal law.

\subsection{Exclusion of Evidence Obtained by Torture or Undue Coercion}

U.S. law criminalizes torture and mandates exclusion for evidence obtained in violation of this prohibition. The United States is a party to the Convention Against Torture (CAT), and the U.S. Congress passed the Torture Act, which criminalizes torture under federal law, to comply with its obligations under CAT. ${ }^{167}$ The Act defines torture as "an act committed by a person acting under the color of law specifically intended to inflict severe physical or mental pain or suffering (other than

\footnotetext{
${ }^{165}$ New York v. Quarles, 467 US 649, 655-56 (1984).

${ }^{166}$ See Wright, 2011.

${ }^{167} 18$ USC $\$ 2340$. The Act provides that "whoever outside the United States commits or attempts to commit torture shall be fined... or imprisoned not more than 20 years, or both, and if death results ... shall be punished by death or imprisoned for any term of years or for life." The federal courts have jurisdiction if "the alleged offender is a national of the United States, or if the alleged offender is present in the United States, irrespective of the nationality of the victim or alleged offender." The Act narrows the scope of mental pain or suffering and limits it to severe mental pain or suffering caused by threats of death, torture, or drugging the victim or third party. The UN Committee Against Torture has requested that the US "ensure that acts of psychological torture were not limited to prolonged mental harm but constituted a wider category of acts, which caused severe mental suffering, irrespective of duration." Luban et al., 2014 at 1162. Torture is already criminalized under US law (for example, torture could be prosecuted as assault and murder under state law), so Section 2340A is meant to apply to torture outside the country. But the UN Committee Against Torture has expressed concern that state prohibitions typically carry lower sentences than the Torture and War Crimes Statutes. Ibid. at 1165-66.

When ratifying CAT, the US Senate added an understanding that the phrase "cruel, inhuman or degrading treatment" means only the kind of treatment forbidden by US constitutional prohibitions on cruel and unusual punishment and on violations of due process law. The Supreme Court has held that government conduct violates due process when it "shocks the conscience." Because the "shock the conscience" test is a sliding scale, lawyers in the Bush administration had argued that certain methods of "enhanced interrogation" used to interrogate suspected terrorists after September 11 would not shock the conscience and were therefore not prohibited by the Torture Act. Luban, 2014 at 122.
} 
pain or suffering incidental to lawful sanctions) upon another person within his custody or physical control."168

While the Torture Act applies to acts committed outside the United States, other state and federal statutes prohibit the use of excessive force by government officials. ${ }^{169}$ These have occasionally given rise to criminal prosecutions. ${ }^{170}$ Civil remedies provide another mechanism of enforcing the ban against torture. ${ }^{171}$

American courts have also aimed to deter police brutality and limit its effects by excluding evidence obtained by torture. As discussed in Sect. 4.1, coerced confessions (i.e., confessions obtained through either coercion or torture) were excluded initially under the common law and subsequently under the Privilege against Self-Incrimination and the Due Process Clause. Under a voluntariness analysis, evidence obtained by any coercion that overwhelms the will of the accused - which is certain to include torture - is inadmissible.

As a preventive matter, safeguards such as Miranda warnings, access to a lawyer (including appointed lawyer when the detainee cannot afford one), and access to medical staff in jail all help prevent undue coercion and torture of detainees. Torture and physical coercion by officers are therefore almost unheard of in civilian settings in the United States today. ${ }^{172}$

\subsection{Debate on Exclusionary Rules}

Debates on exclusionary rules have focused primarily on the exclusion of physical evidence obtained in violation of the Fourth Amendment and statements obtained in violation of Miranda. While commentators have argued about the contours of the law defining coerced statements under the Due Process Clause and the Privilege against Self-Incrimination, exclusion of coerced statements has not been controversial. ${ }^{173}$ This Section therefore focuses on the debates about the Miranda exclusionary rule, which has garnered significant attention from the law enforcement community, lawyers, academic commentators, and the public at large.

\footnotetext{
${ }^{168} 18$ USC $\S 2340$.

${ }^{169}$ See, e.g., 18 USC $\S 113$ (criminalizing assaults within special maritime and territorial jurisdiction of the United States, such as federal land); United States v. Parker, CR-H-83-66 (S.D. Texas 1983), aff'd sub. nom. United States v. Lee, 744 F 2d 1124 (5th Cir. 1984).

${ }^{170}$ See, e.g., United States v. Parker, CR-H-83-66 (S.D. Texas 1983).

${ }^{171}$ Individuals can bring claims for violations of civil rights against state officials under 14 USC $\S$ 1983, and for negligence and intentional torts of federal officials under the Federal Tort Claims Act, 22 USC $\$ 2671$. In addition, the Torture Victims' Protection Act provides US national with a cause of action for torture committed under color of foreign law, and the Alien Tort Claims Act provides a similar cause of action to foreigners. 28 USC $\S 1350$.

${ }^{172}$ This report does not discuss allegations of torture by US agents in military settings after 9/11. For a review of these allegations, see Senate Select Committee on Intelligence, 2014.

${ }^{173}$ See, e.g., Alschuler, 1997; Godsey, 2005; Primus, 2015.
} 
Some commentators have praised Miranda for reducing the coerciveness of interrogations by forcing officers to remember and state the suspects' rights before each interrogation. ${ }^{174}$ Some have also argued that Miranda has been easier to administer, as it provides brighter and more predictable rules for the legality of confessions than the voluntariness test. ${ }^{175}$ Miranda has also been lauded for educating individuals about their rights to remain silent and to consult a lawyer. As the Supreme Court has noted, Miranda has "become part of our national culture" and is thus well-known by a broad segment of the population. ${ }^{176}$

Yet Miranda has also been subject to scrutiny and criticism from the very beginning. When it was first decided, most law enforcement officers were skeptical and resistant. ${ }^{177}$ (Not long afterward, however, empirical studies found that departments complied with "the letter, though not always the spirit" of Miranda rules.) ${ }^{178}$

Some law enforcement officers and scholars have expressed concerns that Miranda has reduced the number of confessions that police have obtained and has thus reduced the crime clearance rate and hurt victims of crime, innocent suspects, and the public at large. ${ }^{179}$ Indeed, several studies have found that Miranda has reduced the number of confessions obtained by police. ${ }^{180}$ A couple have reported a 15-18\% drop in the success rate of obtaining incriminating statements after Miranda; others have found a less significant reduction. ${ }^{181}$ Yet even if Miranda has limited law enforcement's ability to obtain confessions, this has not led to an appreciable loss of convictions, because prosecutors have been able to obtain convictions based on other sources of evidence. ${ }^{182}$

\footnotetext{
${ }^{174}$ Some have argued that it has made law enforcement officers "more professional" in their interrogations. Brief of Griffin B. Bell, et al. as Amici Curiae in Support of Petitioner, Dickerson v. United States, 530 US 428 (2000) (No. 99-5525), cited in Weisselberg, 2008 at 1595; see also Leo, 2001 at 1010 ("[S]ome researchers have argued that Miranda eradicated the last vestiges of third degree interrogation present in the mid-1960s, increased the level of professionalism among interrogators, and raised public awareness of constitutional rights"). Others, however, have argued that "Miranda is ... virtually worthless as a safeguard against specific interrogation practices that were characterized as abusive in the Miranda decision ...." (OLP Report, cited in Cassell, 1996 at 477).

${ }^{175}$ Brief of Griffin B. Bell, et al. as Amici Curiae in Support of Petitioner, Dickerson v. United States, 530 US 428 (2000) (No. 99-5525), cited in Weisselberg, 2008 at 1595.

${ }^{176}$ Dickerson v. United States, 530 US 428, 443 (200).

${ }^{177}$ Leo, 2001 at $1002-03$.

${ }^{178} \mathrm{Ibid}$. at 1003.

${ }^{179}$ E.g., Cassell, 1996 at 115.

${ }^{180}$ Cassell/Hayman, 1996 at 871 (finding a drop from $55-60 \%$ pre-Miranda to $42.2 \%$ postMiranda in the success rate of obtaining confessions); Seeburger/Wettick, 1967 at 12 tbl. 2 (finding that confessions dropped from 48.5\% pre-Miranda to 32.3\% after Miranda); Witt, 1973 at 320 .

${ }^{181}$ For a summary of the studies, some of which conflict in their findings, see Leo, above note 174 , at $1004-06$.

${ }^{182}$ Leo, 2001 at $1004-06$.
} 
Critics of Miranda have argued, however, that the total societal cost of Miranda is higher, as it includes cases that never result in charges being filed (and are therefore not even calculated as "convictions lost"), sentence discounts given during plea bargains to account for possible Miranda violations and for failure to obtain incriminating statements, ${ }^{183}$ and the costs to the judicial system of litigating Miranda issues. Others have disputed these conclusions, as well as the methodology underlying the studies that produced them. ${ }^{184}$ After reviewing the empirical research on Miranda, one scholar argued that "for all practical purposes, Miranda's empirically detectable net damage to law enforcement is zero."185

In short, the question whether Miranda has resulted in an appreciable number of lost confessions or lost convictions continues to be debated. There is, however, broad consensus among scholars that $80-90 \%$ of suspects today waive their Miranda rights and make statements to the police, most of which are incriminating or otherwise helpful to the prosecution. ${ }^{186}$ In addition, even when Miranda violations are raised with courts, these claims are only rarely successful (less than $10 \%$ of the time), at least in part because of the numerous exceptions to the Miranda exclusionary rule that the Court has carved out. ${ }^{187}$ This helps explain why police officers have learned that they can "live" with Miranda. ${ }^{188}$

The high rate of Miranda waivers and the rarity of suppression of Mirandadefective statements provide the basis for a different critique of Miranda safeguards - that they are too ineffectual in preventing coerced and false confessions. Critics point to the $80 \%$ waiver figure to argue that in too many cases, suspects waive their rights, and officers are free to proceed with coercive psychological tactics to procure a confession. Other critics have also pointed out that Miranda has distracted courts from examining the voluntariness of confessions. Once judges see that warnings have been given, they rarely inquire further into the voluntariness of the ensuing confession. ${ }^{189}$ On this view, the warnings regime by Miranda has done little to reduce the psychological pressure that officers place on suspects to confess. ${ }^{190}$

\footnotetext{
${ }^{183}$ Cassell, 1996 at $439-46$.

${ }^{184}$ See, e.g., Leo/Ofshe, 1998 at 557 n. 2; Schulhofer, (1996) 91 at 280; Weisselberg, 1998 at $173-$ 74.

${ }^{185}$ Schulhofer, (1996) 90 at 547.

${ }^{186}$ Cassell, 1996; Leo, 2001 at 1009.

${ }^{187}$ Nardulli, 1983 at 593, 595 tbl. 2, 596, 597 tbl. 7 (finding that motions to suppress confessions were filed in $6.6 \%$ of all cases and that only $2.5 \%$ of these motions were successful); Valdes, 2005 at 1729 (finding that motions to suppress confessions on the basis of Miranda were made in $3.97 \%$ of cases and succeeded $9.86 \%$ of the time).

${ }^{188}$ See, e.g., Leo, 2001 at 1012.

${ }^{189}$ Ibid. at $1025-26$.

${ }^{190}$ Interviews with two Texas defense attorneys and two prosecutors suggest that although physical coercion is a thing of the past, psychological tactics - especially lying to suspects about the evidence in the case-continue to be commonly used. As the defense attorneys interviewed suggested, such tactics, particularly when used with vulnerable (e.g., young or cognitively impaired) suspects, can result in false confessions. See above note 116 .
} 
The problem is said to be particularly acute with respect to certain more vulnerable suspects, such as juveniles, non-native speakers, and mentally disabled suspects, who are most likely to confess falsely as a result of psychological pressure and are least likely to comprehend the Miranda warnings. ${ }^{191}$

Finally, some critics argue that, over time, Supreme Court jurisprudence has weakened the Miranda safeguards to such a point that whatever effectiveness the rule might have had when originally adopted has now been undermined. ${ }^{192}$ Some have accordingly called for a rethinking and strengthening of the voluntariness analysis as an alternative to Miranda, because it is regarded as the only doctrine left to regulate pretrial interrogations in a meaningful way. ${ }^{193}$ Others have called for videotaping - imposed via legislative or judicial means - as the most effective supplement to Miranda in ensuring the voluntariness of confessions. ${ }^{194}$ Finally, another preventive measure that scholars have increasingly proposed to minimize false confessions is the training of police officers in less manipulative interrogation techniques, particularly when interrogating vulnerable suspects. ${ }^{195}$

\section{Conclusion}

Although U.S. law does not expressly impose a duty to search for truth in criminal cases, courts recognize the importance of accurate factfinding to just outcomes and the effective enforcement of criminal law. Yet truthseeking at times must give way to protections of individual rights. The conflict between the search for truth and the protection of rights arises when courts decide whether to exclude unlawfully obtained evidence. When the Constitution does not expressly require exclusion as a remedy, U.S. courts have openly considered the costs of exclusion to the search for truth and have tried to limit those costs. Courts have therefore admitted Mirandadefective confessions for purposes of impeachment, Miranda-defective statements obtained to protect public safety, as well as most fruits of Miranda-defective statements. At the same time, courts always exclude coerced confessions, in part because the Constitution requires such exclusion, in part because of concerns about the confessions' reliability, and in part because of the greater need to deter the police misconduct at issue.

On their own, U.S. exclusionary rules for tainted confessions have not succeeded in eliminating involuntary confessions. Recent DNA exonerations have revealed that false confessions continue to occur and are a leading contributing factor to

\footnotetext{
${ }^{191}$ Weisselberg, 2008 at 1565-68 (discussing studies); see also Garrett, 2012 at 38.

${ }^{192}$ E.g., Weisselberg, 2008.

${ }^{193}$ Primus, 2015.

${ }^{194}$ Interviewees also suggested that videotaping has been very important in reducing coerced confessions in Texas. See above note 116.

${ }^{195}$ See, e.g., Kassin et al., 2010 at 3-38.
} 
wrongful convictions. Accordingly, policymakers and commentators have looked for additional safeguards to prevent the occurrence of such confessions. The main reform being proposed and implemented in this regard is the audio- or video-recording of interrogations. ${ }^{196}$ An increasing number of cities and states are adopting policies and laws requiring such recording. As evidence about the operation of recording becomes available, law enforcement is becoming more receptive to the practice.

Additionally, scholars and police departments are increasingly recognizing the importance of training officers in special techniques for interrogating vulnerable suspects ${ }^{197}$ Such techniques, focused on open-ended questioning rather than psychological manipulation, are expected to minimize the risk of false confessions. ${ }^{198}$

Whatever additional reforms of interrogation practice are adopted, Miranda safeguards and the exclusion of coerced confessions provide an important backstop for regulating police conduct. While imposing some burdens on the search for truth, these procedures encourage police compliance with the Constitution and educate suspects (as well as the population) about their rights.

\section{References}

\section{Books}

Broun, Kenneth S. (ed.), McCormick on Evidence $7^{\text {th }}$ ed., St. Paul 2013. [Broun, 2013]

Garrett, Brandon L., Convicting the Innocent: Where Criminal Prosecutions Go Wrong, Cambridge/Massachusetts/U.S.A. 2012. [Garrett, 2012]

Leo, Richard A., Police Interrogation and American Justice, Cambridge/Massachusetts/U.S.A. 2008. [Leo, 2008]

Luban, David, et al., International and Transnational Criminal Law $2^{\text {nd }}$ ed., July 2014. [Luban et al., 2014]

Luban, David, Torture, Power, and Law, October 2014. [Luban, 2014]

Miller, Marc L./Wright, Ronald F., Criminal Procedures: The Police, July 2007. [Miller/Wright, 2007]

Saltzburg, Stephen A./Capra, Daniel J., American Criminal Procedure: Cases and Commentary $10^{\text {th }}$ ed., May 2014. [Saltzburg/Capra, 2014]

Tomkovicz, James J., Constitutional Exclusion, New York 2011. [Tomkovicz, 2011]

\footnotetext{
${ }^{196}$ See above Part 3.4.2; see also Cassell, 1997 at 1132 (noting that "there seems to be virtual unanimity among those who have reviewed the problem that videotaping interrogations is an effective solution to the false confession problem"). Other proposed reforms include replacing police interrogations with questioning by a neutral magistrate (Amar/Lettow, 1995), reinforced corroboration rules, including mandatory DNA testing (Drizin/Leo, 2004 at 1006), and training police officers about the causes of false confessions (Ibid.).

${ }^{197}$ See, e.g., Cleary/Warner, 2016 at 282; Kassin et al., 2010 at 3-38.

${ }^{198}$ For a comparative review of interrogation policies and training, see, for example, Dixon, 2019.
} 


\section{Journal Articles}

Alschuler, Albert W., 'Constraint and Confession', (1997) 74 Denver University Law Review, 957-978. [Alschuler, 1997]

Amar, Akhil/Lettow, Renee Lerner, 'Fifth Amendment First Principle: The Self-Incrimination Clause', (1995) 93 Michigan Law Review, 857-928 [Amar/Lettow, 1995]

Brown, Darryl K., 'The Decline of Defense Counsel and the Rise of Accuracy in Criminal Adjudication', (2005) 93 California Law Review, 1585-1646. [Brown, 2005]

Cassell, Paul/Hayman, Bret, 'Police Interrogation in the 1990s: An Empirical Study of the Effects of Miranda', (1996) 43 UCLA Law Review, 839-931. [Cassel1/Hayman, 1996]

Cassell, Paul G., 'Balanced Approaches to the False Confession Problem: A Brief Comment on Ofshe, Leo, and Alschuler', (1997) 74 Denver University Law Review, 1123-1133. [Cassell, 1997]

Cassell, Paul G., 'Miranda's Social Costs: An Empirical Reassessment', (1996) 90 Northwestern University Law Review, 387-499. [Cassell, 1996]

Cleary, Hayley M. D./Warner, Todd C., 'Police Training in Interviewing and Interrogation Methods: A Comparison of Techniques Used with Adult and Juvenile Suspects', (2016) 40 Law \& Human Behavior, 270-284. [Cleary/Warner, 2016]

Drizin, Steven A./Leo, Richard A., 'The Problem of False Confessions in the Post-DNA World', (2004) 82 North Carolina Law Review, 891-1004 [Drizin/Leo, 2004]

Fisher, Stanley Z., “'Just the Facts, Ma'am": Lying and the Omission of Exculpatory Evidence in Police Reports', (1993) 28 New England Law Review, 1-62. [Fisher, 1993]

Fisher, Talia/Rosen-Zvi, Issachar, 'The Confessional Penalty', (2008) 30 Cardozo Law Review, 871-916. [Fisher/Rosen-Zvi, 2008]

Geller, William, 'Enforcing the Fourth Amendment: The Exclusionary Rule and Its Alternatives', (1975) 1975 Washington University Law Quarterly, 621-722. [Geller, 1975]

Gershowitz, Adam/Killinger, Laura R., 'The State (Never) Rests: How Excessive Prosecutorial Caseloads Harm Criminal Defendants', (2011) 105 Northwestern University Law Review, 261301. [Gershowitz, 2011]

Godsey, Mark A., 'Rethinking the Involuntary Confession Rule: Toward a Workable Test for Identifying Compelled Self-Incrimination', (2005) 93 California Law Review, 465-540. [Godsey, 2005]

Kamisar, Yale, 'On the 'Fruits' of Miranda Violations, Coerced Confessions, and Compelled Testimony', (1995) 93 Michigan Law Review, 929-1010. [Kamisar, 1995]

Kassin, Saul M., et al., 'Police-induced Confessions: Risk Factors and Recommendations', (2010) 34 Law and Human Behavior, 3-38. [Kassin et al., 2010]

Laurin, Jennifer E., 'Quasi-Inquisitorialism: Accounting for Deference in Pretrial Criminal Procedure', (2014) 90 Notre Dame Law Review, 783-846. [Laurin, 2014]

Leo, Richard A./Ofshe, Richard J., 'Using the Innocent to Scapegoat Miranda: Another Reply to Paul Cassell', (1998) 88 Journal of Criminal Law \& Criminology, 557-577. [Leo/Ofshe, 1998]

Leo, Richard A., 'Questioning the Relevance of Miranda in the Twenty-First Century', (2001) 99 Michigan Law Review, 1000-1029. [Leo, 2001]

Luna, Erik/Wade, Marianne, 'Prosecutors as Judges', (2010) 67 Washington and Lee Law Review, 1413-1532. [Luna/Wade, 2010]

Nardulli, Peter F., 'The Societal Cost of the Exclusionary Rule: An Empirical Assessment', (1983) 1983 American Bar Foundation Research Journal, 585-609. [Nardulli, 1983]

Pepson, Michael D./Sharifi, John N., 'Lego v. Twomey: The Improbable Relationship Between an Obscure Supreme Court Decision and Wrongful Convictions', (2010) 47 American Criminal Law Review, 1185-1250. [Pepson/Sharifi, 2010]

Primus, Eve Brensike, 'The Future of Confession Law: Toward Rules for the Voluntariness Test', (2015) 114 Michigan Law Review, 1-56. [Primus, 2015]

Richman, Daniel C., 'Federal Criminal Law, Congressional Delegation, and Enforcement Discretion', (1999) 46 UCLA Law Review, 757-814. [Richman, 1999] 
Richman, Daniel C., 'Prosecutors and Their Agents, Agents and Their Prosecutors', (2003) 103 Columbia Law Review, 749-832. [Richman, 2003]

Schulhofer, Stephen J., 'Miranda and Clearance Rates', (1996) 91 Northwestern University Law Review, 278-294. [Schulhofer, (1996) 91]

Schulhofer, Stephen J., 'Miranda's Practical Effect: Substantial Benefits and Vanishingly Small Social Costs', (1996) 90 Northwestern University Law Review, 500-563. [Schulhofer, (1996) 90]

Schwartz, Joanna C., 'What Police Learn from Lawsuits', (2012) 33 Cardozo Law Review 841894. [Schwartz, 2012]

Seeburger, Richard/Wettick, Stanton, 'Miranda in Pittsburgh-A Statistical Study', (1967) 29 University of Pittsburgh Law Review, 1-26. [Seeburger/Wettick, 1967]

Sklansky, David Alan, 'Is the Exclusionary Rule Obsolete?', (2008) 5 Ohio State Journal of Criminal Law, 567-584. [Sklansky, 2008]

Stacy, Tom, 'The Search for the Truth in Constitutional Criminal Procedure', (1991) 91 Columbia Law Review 1369-1451. [Stacy, 1991]

Taslitz, Andrew E., 'High Expectations and Some Wounded Hopes: The Policy and Politics of A Uniform Statute on Videotaping Custodial Interrogations', (2012) 7 Northwestern Journal of Law \& Social Policy, 400-454. [Taslitz, 2012]

Tomkovicz, James J., 'Sacrificing Massiah: Confusion over Exclusion and Erosion of the Right to Counsel', (2012) 16 Lewis \& Clark Law Review, 1-67. [Tomkovicz, 2012]

Turner, Jenia Iontcheva, 'Judicial Participation in Plea Negotiation: A Comparative View', (2006) 54 American Journal of Comparative Law, 199-267. [Turner, 2006]

Valdes, Stephen G., 'Frequency and Success: An Empirical Study of Criminal Law Defenses, Federal Constitutional Evidentiary Claims, and Plea Negotiations', (2005) 153 University of Pennsylvania Law Review, 1709-1814. [Valdes, 2005]

Weisselberg, Charles D., 'Mourning Miranda', (2008) 96 California Law Review, 1519-1602. [Weisselberg, 2008]

Weisselberg, Charles D., 'Saving Miranda', (1998) 84 Cornell Law Review, 109-192. [Weisselberg, 1998]

Witt, James, 'Non-Coercive Interrogation and the Administration of Criminal Justice: The Impact of Miranda on Police Effectuality', (1973) 64 Journal of Criminal Law \& Criminology, 320 332. [Witt, 1973]

Wright, Joanna, 'Mirandizing Terrorists? An Empirical Analysis of the Public Safety Exception', (2011) 111 Columbia Law Review, 1296-1331. [Wright, 2011]

\section{Contributions to Edited Volumes and Annotated Law}

Cammack, Mark E., 'The United States: The Rise and Fall of the Constitutional Exclusionary Rule', in: S. C. Thaman (ed.), Exclusionary Rules in Comparative Law, New York 2013, 3-32. [Cammack, 2013]

David Dixon, 'Interrogation Law and Practice in Common Law Jurisdictions', in: D. Brown et al. (eds.), Oxford Handbook of Criminal Process, forthcoming 2019. [Dixon, 2019]

\section{Reports, Legislative History}

Finn, Peter, 'Citizen Review of Police: Approaches and Implementation', (National Institute of Justice 2001). [Finn, 2001] <https://www.ncjrs.gov/pdffiles1/nij/184430.pdf>, accessed 1 November 2018.

Geller, William, 'Videotaping Interrogations and Confessions: National Institute of Justice Research in Brief' (National Institute of Justice 1993). [Geller, 1993] 
Innocence Project, 'The Causes: False Confessions or Admissions', (2017). [Innocence Project, 2017] <https://www.innocenceproject.org/causes/false-confessions-admissions >, accessed 1 November 2018.

Judicial Council of California, Administrative Office of the Courts, 'Fact Sheet: Cameras in the California Courts, (Feb. 2007). [Judicial Council of California, Administrative Office of the Courts, 2007] <http://www.courts.ca.gov/documents/camerasc.pdf>, accessed 1 November 2018.

'Memorandum from James M. Cole, Deputy Att'y Gen., to Assoc. Att'y Gen. et al.', (12 May 2014). [Memorandum from James M. Cole, 2014] <http://s3.documentcloud.org/documents/ 1165406/recording-policy.pdf>, accessed 1 November 2018.

Miller, Lindsay et al., 'Implementing a Body-Worn Camera Program: Recommendations and Lessons Learned', (2014). [Miller et al., 2014] <http://www.justice.gov/iso/opa/resources/ 472014912134715246869 .pdf $>$, accessed 1 November 2018.

Office of Legal Policy, U.S. Dep't of Justice, 'Report to the Attorney General on The Law of Pre-Trial Interrogation', (1986) 99, reprinted in (1989) 22 University of Michigan Journal of Law Reform, 437-572. [Office of Legal Policy, 1989]

Senate Select Committee on Intelligence, 'Committee Study of the Central Intelligence Agency's Detention and Interrogation Program, Findings and Conclusions', (2014). [Senate Select Committee on Intelligence, 2014] <http://www.intelligence.senate.gov/sites/default/files/press/ findings-and-conclusions.pdf>, accessed 1 November 2018.

Sullivan, Thomas P., Nat'l Ass'n of Criminal Def. Lawyers, 'Compendium: Electronic Recording of Custodial Interrogations', (2014). [Sullivan, 2014] <https://www.nacdl.org/WorkArea/ DownloadAsset.aspx ?id=33287\&libID=33256>, accessed 1 November 2018.

Jenia Iontcheva Turner is the Amy Abboud Ware Centennial Professor in Criminal Law at SMU Dedman School of Law, where she teaches criminal procedure, comparative criminal procedure, criminal procedure in the digital age, international criminal law, and international law. She is the author of "Plea Bargaining Across Borders" (2009) and co-editor of "The Oxford Handbook of Criminal Process" (forthcoming 2019) and "Criminal Procedures: Cases, Statutes, and Executive Materials" (as of the 6th ed. 2019).

Open Access This chapter is licensed under the terms of the Creative Commons Attribution 4.0 International License (http://creativecommons.org/licenses/by/4.0/), which permits use, sharing, adaptation, distribution and reproduction in any medium or format, as long as you give appropriate credit to the original author(s) and the source, provide a link to the Creative Commons license and indicate if changes were made.

The images or other third party material in this chapter are included in the chapter's Creative Commons license, unless indicated otherwise in a credit line to the material. If material is not included in the chapter's Creative Commons license and your intended use is not permitted by statutory regulation or exceeds the permitted use, you will need to obtain permission directly from the copyright holder. 